\title{
Household Inflation Expectations and Consumer Spending: Evidence from Panel Data
}

\author{
Mary A. Burke and Ali Ozdagli
}

\begin{abstract}
:
With nominal interest rates at the zero lower bound, an important question for monetary policy is whether, as predicted in prior theoretical work, an increase in inflation expectations would boost current consumer spending. Using survey panel data for the period from April 2009 to November 2012, we examine the relationship between a household's inflation expectations and its current spending, taking into account other factors such as the household's wage growth expectations, the uncertainty surrounding its inflation expectations, macroeconomic conditions, and unobserved heterogeneity at the household level. We examine spending behavior for large consumer durables as well as for nondurable goods. No evidence is found that consumers increase their spending on large home appliances and electronics in response to an increase in their inflation expectations. In most models, the estimated effects are small, negative, and statistically insignificant. However, consumers do appear more likely to purchase a car as their short-run inflation expectations rise. Additionally, in some models, spending on nondurable goods increases with short-run expected inflation. These estimated effects on nondurables spending are modest, not highly robust, and appear to be driven by the behavior of homeowners who did not have a mortgage. These findings are surprising because theory predicts that consumption of durable goods should be more sensitive to real interest rates than consumption of nondurable goods. In addition, consumers in our sample, on average, did not expect their nominal income growth to match inflation, and therefore an increase in expected inflation would create a negative income effect that discourages spending in both the present and the future. The findings suggest that, as a policy measure, raising inflation expectations may not be effective in boosting present consumption.
\end{abstract}

\section{JEL Classifications: D12, D84, D91, E52}

Mary A. Burke is a senior economist in the research department at the Federal Reserve Bank of Boston. Her e-mail address is mary.burke@bos.frb.org. Ali Ozdagli is a senior economist in the research department at the Federal Reserve Bank of Boston. His e-mail address is ali.ozdagli@bos.frb.org.

This paper presents preliminary analysis and results intended to stimulate discussion and critical comment. The views expressed herein are those of the authors and do not indicate concurrence by the Federal Reserve Bank of Boston, by the principals of the Board of Governors, or by the Federal Reserve System.

This paper, which may be revised, is available on the web site of the Federal Reserve Bank of Boston at http://www.bostonfed.org/economic/wp/index.htm.

This version: December 18, 2013. 


\section{Introduction}

The relationship between household inflation expectations and consumer spending holds important implications for monetary policy, particularly in a zero lower bound (ZLB) environment. Drawing on the theoretical work of Krugman (1998), Eggertsson and Woodford (2003), and other researchers, participants in recent monetary policy debates have argued that the Federal Reserve should commit to policies that raise expectations of future inflation, thereby effecting a decline in real interest rates and encouraging greater current spending (as reported, for example, by Appelbaum 2013). According to theory, purchases of large consumer durables and residential housing, purchases that are readily substituted across time and that are often financed with debt, should be particularly sensitive to an increase in expected inflation that lowers real borrowing rates. Christina Romer argued in 2011 that "in the current situation...a small increase in expected inflation could be helpful. It would lower real borrowing costs, and encourage spending on big-ticket items like cars, homes and business equipment” (Romer 2011). In this argument, the current situation refers to an environment in which the ZLB imposes a binding constraint on the observed nominal short-term interest rate because the nominal short-term rate that would be realized in the absence of the ZLB, the shadow nominal interest rate, would be negative. In such an environment, an increase in expected inflation might raise the shadow nominal rate but not the observed nominal rate, leading to a decline in the real interest rate, as long as the shadow nominal rate remains below zero. Since the financial crisis, both Krugman and Rogoff have consistently advocated for higher inflation, ${ }^{1}$ and Woodford (2012) has promoted nominal GDP targeting, which works in part through its effects on inflation expectations. Looking back to an earlier liquidity trap episode, Eggertsson (2008) argues that an increase in expected inflation contributed to ending the Great Depression.

Microeconomic data are needed to identify a causal relationship between individual household inflation expectations and spending behavior, yet the microeconomic evidence addressing this question is scarce. Only two previous studies have used micro data to examine the relationship between inflation expectations and consumer spending, and both have produced mixed results. Using data from the University of Michigan Survey of Consumers, Bachmann, Berg, and Sims (2012) find no significant relationship between inflation expectations and the "readiness to spend" on durable goods. If anything, they find that higher expected inflation has an adverse impact on the propensity to spend. In contrast, using data from a Bank of Japan survey of consumer opinions, Ichiue and Nishiguchi (2013) find

\footnotetext{
${ }^{1}$ Krugman's arguments have appeared repeatedly in his New York Times column and on his blog; one such example is Krugman (2013). Rogoff's arguments have also appeared repeatedly in the New York Times (for example, Norris 2011) and numerous other print, radio, and online news outlets, including, recently, Bloomberg.com (Ito and Jamrisko 2013).
} 
evidence that supports the prediction that higher expected inflation boosts current spending in a ZLB environment.

Both studies face significant data limitations. Bachmann, Berg, and Sims (2012) relies on hypothetical “readiness-to-spend” data rather than on actual spending data. While average "readiness to spend” is correlated with aggregate spending in the NIPA accounts, the relationship between individual readinessto-spend and individual spending is not observed. Ichiue and Nishiguchi (2013) employs data on actual, over-the-year spending changes and planned, one-year-ahead spending changes. While less hypothetical than the Michigan survey's readiness-to-spend measure, these measures may be subject to psychological biases that limit their accuracy. ${ }^{2}$ In addition, these spending changes are limited to categorical values, as are the measures of expected inflation used in the same study. In addition, both of the previous studies identify effects using variation in behavior across households rather than variation within households over time, and therefore they cannot control for unobserved heterogeneity among households.

In this paper, we revisit the relationship between household inflation expectations and consumer spending by using panel survey data from the New York Fed/RAND-American Life Panel household expectations survey (RAND American Life Panel; Bruine de Bruin et al. 2011). This dataset contains detailed self-reports of actual spending on a comprehensive list of goods, including both durables and nondurables. The panel dimension allows us to control for unobserved heterogeneity at the household level, a step that significantly alters the results yielded by some models. We identify our coefficient estimates using changes in spending over time within individual households, where the changes are derived from repeated reports of the household's spending levels. Furthermore, survey respondents provide information that approximates a complete probability distribution over future inflation expectations, rather than giving only a point estimate of expected future inflation (as in the Michigan Survey) or a categorical expectation (as in the Bank of Japan survey). With these data, we are able to examine the response of numerous components of spending to changes in multiple moments of the future inflation distribution, using what are arguably better measures of both the independent and dependent variables, and employing a more robust identification strategy than used in previous studies.

We examine spending behavior for large consumer durable goods, such as refrigerators and televisions, as well as for nondurable goods. We find no evidence that consumers increase their spending on large home appliances and electronics in response to an increase in their inflation expectations; in most models the estimated effects are small, negative, and statistically insignificant. However, consumers do appear more likely to purchase a car -17 percent over the baseline purchase risk-as their inflation

\footnotetext{
${ }^{2}$ Hurd and Rohwedder (2013) find that survey respondents have a difficult time recalling spending levels for the previous year. Planned future spending changes may reflect subjects' best intentions, which may be biased downward.
} 
expectations rise by 1 percentage point. In addition, spending on nondurable goods increases with expected inflation in some models, but the estimated average treatment effects are small and not highly robust. By one estimate, a 1 percentage point increase in expected one-year-ahead inflation increases current-month spending on nondurable items (including clothing, food, utilities, health care, and a number of other goods and services) by 1.1 percent, or roughly $\$ 21$ at the average monthly spending level (for nondurable goods) in our sample.

Controlling for unobserved heterogeneity at the household level is important: most of the cases in which we observe statistically significant positive or negative relationships between inflation expectations and spending arise in models that control for household fixed effects. Our results for spending on durable goods imply that some subjects tend to hold higher inflation expectations than other subjects and also tend to spend more on durable goods, all else being equal. Consequently, a finding from cross-sectional evidence that inflation expectations have a positive effect on spending may not reflect a true treatment effect. Previous studies have identified that there is significant heterogeneity in inflation expectations which tend to be correlated with factors such as financial literacy (see Bruine de Bruine et al. 2010; Burke and Manz 2011).

Facts that may be specific to the period being examined may help to explain some of our unexpected findings - for example, the fact that spending on large durable goods does not respond more strongly to inflation expectations - and may even respond negatively-compared to spending on other goods. During a large portion of our sample period, the prices for large appliances were either falling in absolute terms, or at least falling relative to the overall consumer price index, a fact that may help to explain our results. Because we do not observe consumers' expectations of inflation in appliance prices, however, we cannot control for the role such expectations play in their spending behavior.

Consumers in our sample, on average, expected negative real wage growth, consistent with the fact that the U.S. median real wage exhibited declines between mid-2008 and late 2012. In such a context, any incentives generated by higher expected inflation to increase present consumption may have been blunted by concomitant expectations of falling real wages. Creditor households may have reduced their consumption further because for these households higher expected inflation would have caused a decline in expected real wealth. Although we control for a measure of expected real wage growth, such controls are likely to be imperfect, and we cannot control for expected real wealth. Earlier survey evidence from Shiller (1997) indicates that people dislike inflation because they believe it will erode their standard of living. In evaluating inflation policy, therefore, it will be important to gain a better understanding of the relationship between inflation expectations and wage expectations as these evolve under various economic conditions. In terms of a bottom line policy implication, our results indicate that promoting 
higher inflation expectations may be insufficient for boosting present consumption, and in some cases higher inflation expectations may actually discourage consumption.

\section{Background and Related Literature}

It is useful to first review the basic economic logic underpinning the prediction that an increase in expected inflation should boost current consumption. This prediction draws on the Fisher equation that approximates the real rate of interest as the difference between the nominal interest rate and the expected inflation rate. In this equation, a given change in expected inflation has the same effect on the real interest rate, keeping the nominal rate constant, as does an equal but opposite change in the nominal interest rate, keeping the inflation expectations constant. In the standard intertemporal choice framework, a decline in the real interest rate encourages substitution toward present consumption. While an income effect may offset the substitution effect, empirical macroeconomic evidence generally supports the notion that the substitution effect dominates (see, for example, Christiano, Eichenbaum, and Evans. 2005).

Describing the problem in more detail, however, reveals that the effect of an increase in expected inflation on current consumption need not be equivalent to the effect of a decrease in the nominal interest rate. Consider a two-period choice problem — the periods being "present" and "future" — with a single consumption good. The present price of the good is denoted as $p_{0}$. Letting $\pi_{\mathrm{e}}$ denote the expected rate of inflation between the present and the future, the expected future price of the good is given by $p_{0}\left(1+\pi_{e}\right)$. The consumer receives a known amount of nominal income in the present, denoted by $y_{0}$, and an expected nominal amount in the future, denoted as $y_{1 e}$, not including interest earned (paid) on savings (borrowings) made in the present. These income endowments are net of existing (inherited) debt or bequests. Therefore, endowments can be negative (positive) if, for example, pre-committed debt payments exceed (fall short of) cash inflows and bequests. The consumer can save and borrow at nominal interest rate $i$, which represents the nominal rate of return on savings or the nominal interest rate on debt. She chooses present consumption, denoted $c_{0}$, and planned future consumption, $c_{1 e}$, to maximize the expected present discounted value of utility, subject to a present-value budget constraint. The budget constraint can be written as follows: ${ }^{3}$

$$
p_{0} c_{0}+\frac{1}{1+i} p_{0}\left(1+\pi_{e}\right) c_{1 e}=y_{0}+\frac{1}{1+i} y_{1 e}
$$

\footnotetext{
${ }^{3}$ Here and in the following discussion we are implicitly assuming that changes in inflation expectations do not systematically and significantly affect the covariance of future consumption and income with inflation, as is implicitly assumed in empirical studies. More specifically, we can write $p_{0} c_{0}+\frac{1}{1+i} p_{0} E\left[(1+\pi) c_{1}\right]=y_{0}+$ $\frac{1}{1+i} E\left[y_{1}\right]$, which gives our present-value budget constraint once we define $y_{1 e}=E\left[y_{1}\right]-\operatorname{cov}\left(\pi, c_{1}\right)$.
} 
If the consumer's future income is indexed to inflation, we can substitute $y_{1 e}$ with $y_{1}\left(1+\pi_{e}\right)$, where $y_{1}$ represents expected future nominal income in present dollars. In this case, it is apparent that an increase in expected inflation, keeping the nominal interest rate constant, would have similar incentive effects on consumption as would a decrease of a similar magnitude in the nominal interest rate, keeping expected inflation constant. However, although in the aggregate income growth should track inflation in the long run, in the short run several components of future income may be sticky. One obvious example is wages: Barattieri, Basu, and Gottschalk (2010) show that while the probability of a wage change is positively correlated with consumer price inflation (CPI), this correlation is far from perfect and, in the average quarter, the probability that an individual will experience a nominal wage change is between 5 and 18 percent. Existing debt payments also are often nominally fixed, at least in the short run, because refinancing fixed-rate debt is not optimal when the interest rate rises and is costly even when the interest rate falls, since the interest rate on floating-rate debt takes time to adjust. Finally, for both fixed-rate and floating-rate debt, the debt principal is typically fixed in nominal terms.

As an illustration, in the extreme case where expected future nominal income does not react to monetary policy, an increase in expected inflation would only increase the price of the future consumption good, $p_{0}\left(1+\pi_{e}\right)$, and create the textbook substitution and income effects. The substitution effect would increase present consumption and reduce expected future consumption. The income effect that arises because higher expected inflation reduces the present discounted value of expected real net income would reduce both present and expected future consumption. Since neither the nominal interest rate nor nominal income changes, the impact of an increase in expected inflation is limited to these latter effects.

Holding expected future net nominal income fixed, a decrease in the nominal interest rate also raises the relative price of future consumption, $\frac{p_{0}\left(1+\pi_{e}\right)}{1+i}$, and therefore creates similar substitution and income effects as does an increase in expected inflation. However, a decrease in the nominal interest rate also has a direct wealth effect on the expected present discounted value of future nominal income, $\frac{y_{1 e}}{1+i}$. Moreover, this wealth effect depends on whether the consumer expects future nominal income to be positive or negative. If expected future nominal income is positive, then the present discounted value of income increases with a decrease in the nominal interest rate, and there is a positive wealth effect that at least partly offsets the negative income effect. Therefore, present consumption reacts more positively than it would to an increase in expected inflation. Analogously, if expected future nominal net income (after any pre-scheduled expenses) is negative, so that $y_{1 e}<0$, the resulting negative wealth effect will reinforce the income effect, and present consumption will increase by less (or decrease by more) than it would in the absence of the wealth effect. 
As Ichiue and Nishiguchi (2013) point out, the predicted negative relationship between real interest rates and spending is therefore a purely empirical matter. As discussed in both Ichiue and Nishiguchi (2013) and Bachman, Berg, and Sims (2012), however, the existing macroeconomic evidence is typically identified based on movements in nominal interest rates, holding inflation constant, rather than on movements in inflation expectations, holding nominal rates constant. In addition to the issues raised above, Bachman, Berg, and Sims (2012) argue that nominal interest rates may be more salient than inflation as indicators of real rates, in effect similar to money illusion in nominal income. Wiederholt (2012) shows that in a model with dispersed information, a commitment by policymakers to higher inflation may send negative signals about the future outlook for the economy, thereby reducing current consumption.

An economic environment in which monetary policy is constrained by the ZLB therefore represents an important opportunity in which to test the effects of variation in inflation expectations, as nominal rates should not be expected to move in a manner that fully offsets changes in expected inflation. When the ZLB on the short-term monetary policy rate is binding, the shadow (unconstrained) short-term nominal interest rate is negative, but the actual nominal interest rate is bounded by zero. A small increase in expected inflation that raises the optimal short-term nominal interest rate slightly, but still leaves it negative, would leave the effective short-term nominal rate at zero and therefore lower the real short-term rate. While longer-term nominal rates need not be similarly stuck at zero, the policy argument requires that longer-term nominal borrowing rates not rise as much as expected inflation. When the ZLB is not binding, the effect of an increase in inflation expectations on real rates, whether short term or long term, depends on the relationship between the expected inflation rate and the monetary authority's inflation target-but the likelihood of nominal rate adjustments is higher in a non-ZLB setting. In our sample, people did not, on average, expect their wage growth to keep up with inflation, a factor which may have negatively affected their response to expected inflation. Keeping this issue in mind, our estimation strategy controls for a measure of the household's expected real wage growth, a measure intended to isolate the predicted positive effects of higher expected inflation on consumption. However, because expected real wage growth is likely to be measured with error, this control will be imperfect. We are not

able to observe real net worth, a factor that also may influence the response of present consumption to inflation expectations, as described above.

\section{Data: Measures and Description}

A. Inflation Forecasts and Personal Wage Growth Forecasts 
The data on expectations of price inflation, wage growth, and other economic conditions are drawn from a series of survey modules appended to RAND's American Life Panel (ALP) during the period dating from May 2008 through November 2012, administered at a roughly six-week frequency. The survey modules were designed by a team of researchers from the Federal Reserve Bank of New York and various academic institutions. Bruine de Bruin et al. (2011, pp. 3-4) describe the key feature of the survey modules as follows:

[The] surveys... allow respondents to report their point forecasts as well as their density forecasts for price and wage inflation. The questions about density forecasts ask respondents to assign probabilities to predetermined intervals or bins for future changes in the general price level and in wage earnings (e.g., go down by $0 \%$ to $2 \%$, go up by $0 \%$ to $2 \%$, go up by $2 \%$ to $4 \%$, etc.).

The resulting density forecasts can then be used to construct individual measures of central tendency (we use the density median) and uncertainty (we use the interquartile range). To construct these measures, we follow the method used by Bruine de Bruin et al. (2011) and Engelberg, Manski, and Williams (2009). ${ }^{4,5}$ These methods yield the key independent variables of interest, described in Table A below. ${ }^{6}$ Additional control variables are described in Table B, immediately following Table A.

Table A. Key Independent Variables

\begin{tabular}{|l|l|}
\hline Variable Name & Description \\
\hline $\begin{array}{l}\text { Expected Inflation, } \\
\text { short run (medium run) }\end{array}$ & $\begin{array}{l}\text { Median of individual density function over short-run (year-ahead) or } \\
\text { medium-run (between two and three years ahead) inflation }\end{array}$ \\
\hline $\begin{array}{l}\text { Inflation Uncertainty, } \\
\text { short run (medium run) }\end{array}$ & $\begin{array}{l}\text { Interquartile range of individual density function over short-run or } \\
\text { medium-run inflation }\end{array}$ \\
\hline $\begin{array}{l}\text { Expected Nominal Wage } \\
\text { Growth (short run only) }\end{array}$ & $\begin{array}{l}\text { Median of individual density function over percent change in own wage } \\
\text { (at same job) in coming 12 months }\end{array}$ \\
\hline $\begin{array}{l}\text { Expected real wage growth } \\
\text { (short run only) }\end{array}$ & $\begin{array}{l}\text { Difference between expected nominal wage growth (defined above) and } \\
\text { expected inflation (defined above), both at short-run horizon }\end{array}$ \\
\hline
\end{tabular}

Table B: Additional Control Variables (Not Including Fixed Effects)

\footnotetext{
${ }^{4}$ The method involves fitting a beta distribution to the points on the individual cumulative distributive function, which can be directly inferred from the probabilities on the various bins. When positive probability is placed on only two or fewer bins, the method assumes that the density function has the shape of an isosceles triangle. For further details on the method, see Engelberg, Manski, and Williams (2009).

${ }^{5}$ We thank Brandi Coates, Giorgio Topa, and Wilbert van der Klaauw of the New York Fed for providing us with the code needed to perform these operations on the data.

${ }^{6}$ To construct the expected (density median) real wage growth, we simply subtract the density median of the inflation forecast from the density median of the nominal wage growth forecast, despite the fact that we do not know the true joint distribution of the inflation forecast and the nominal wage growth forecast. Alternatively, we can compute the density mean of future real wage growth as the difference between the respective density means of nominal wage growth and inflation. On average, the assumed medians and means are not significantly different and the results are robust, so we use medians for consistency with the remainder of the analysis. However, without knowing the full joint distribution, we cannot construct an interquartile range for real wage growth, and so we control only for the uncertainty in nominal wage growth.
} 


\begin{tabular}{|l|l|}
\hline Variable Name & Description \\
\hline $\begin{array}{l}\text { Real Household Income (in logs, except as noted } \\
\text { below) }\end{array}$ & $\begin{array}{l}\text { Self-reported current monthly household income, } \\
\text { expressed in 2012 dollars }\end{array}$ \\
\hline (Nominal) Wage Growth Uncertainty & $\begin{array}{l}\text { Interquartile range of the individual density } \\
\text { function for nominal wage growth }\end{array}$ \\
\hline $\begin{array}{l}\text { Discrete Expected Change in Aggregate } \\
\text { Unemployment }\end{array}$ & $\begin{array}{l}\text { Respondents selected among “unemployment up”; } \\
\text { "unemployment down”; "about the same.” }\end{array}$ \\
\hline $\begin{array}{l}\text { Discrete Expectation for Change in “Interest Rates } \\
\text { for Borrowing Money” over the next 12 Months }\end{array}$ & $\begin{array}{l}\text { Respondents selected among “go up,” "go down,” } \\
\text { or “stay the same.” }\end{array}$ \\
\hline Demographic Characteristics & $\begin{array}{l}\text { Dummy variables for white race (vs. non-white), } \\
\text { female, and retirement status; continuous variable } \\
\text { for age in years }\end{array}$ \\
\hline
\end{tabular}

\section{B. Spending Measures}

The ALP also conducts regular survey modules about household spending based on an extensive list of spending categories. These modules are separate from the modules described above that polled subjects about their inflation (and other) expectations, but there is substantial overlap (that varies over time) between the set of respondents to the regular survey modules and the set of respondents to the modules appended to the RAND/ALP that asked about inflation expectations. The spending modules ask the respondent to report on spending on specific items or groups of items by the entire household in either the last calendar month (for frequently purchased items such as food) or, in the case of infrequently purchased items (including big-ticket durable goods such as refrigerators), in the last three calendar months. ${ }^{7}$ Hurd and Rohwedder (2013) find that the ALP survey’s (weighted) household average total spending for 2010 (aggregated over the year and across all spending categories) lines up closely with average household spending for 2010 as measured in the Consumer Expenditure Survey conducted by the Bureau of Labor Statistics. They also point to evidence that surveys that ask about prior-year spending are subject to significant recall bias and consequently argue that consumer spending should be polled at a quarterly or monthly frequency.

We observe monthly spending on the frequently purchased items for the period from April 2009 through November 2012. We use these data to construct an unbalanced panel of monthly spending on "nondurable” items such as food, clothing, personal care goods and services, utilities, medical expenditures and others listed in the table on the following page. (We omit rent/mortgage payments and car payments in order to isolate frequently purchased consumer goods.) To obtain estimated real spending values, we deflate the nondurable spending values by the CPI-U for 2012. We observe quarterly spending on the infrequently purchased items beginning in 2009:Q2 and ending with 2011:Q2. ${ }^{8}$ We use these

\footnotetext{
${ }^{8}$ Beginning in October 2011, the ALP began asking about spending on the infrequent/big-ticket items at a monthly frequency. In order to extend the quarterly series on durable goods to include the later period, we sum the monthly
} 
quarterly data to construct an unbalanced panel of quarterly durable goods spending on items such as refrigerators, televisions, and other goods listed in Table $\mathrm{C}$ below. For this spending series, we use the appliances price index (“CPI-U appliances”) for 2012 as the deflator (although the results are qualitatively robust when deflating by the overall CPI-U). We do not include insurance payments, which are also polled at a quarterly frequency, because this expenditure category is very different from durable goods, and is presumably less sensitive to interest rates. In addition to quarterly spending on durable goods, we construct a quarterly series of the total number of large durable goods purchased, because the extensive margin of durables purchases may be more sensitive to real interest rates than the total amount spent. In addition, this measure is robust to the choice of price deflator. For additional analysis, we also construct a quarterly time series of the discrete purchase decision for each of a number of big-ticket items, including cars and all the appliances named below, but excluding furniture.

Table C, immediately below, describes the goods included, respectively, in each of the different spending measures used as dependent variables in the regression analysis:

Table C: Dependent Variables and Descriptions

\begin{tabular}{|l|l|}
\hline $\begin{array}{l}\text { Non-Durables Spending } \\
\text { (monthly frequency) }\end{array}$ & $\begin{array}{l}\text { Clothing, food (at home and away), utilities } \\
\text { (phone/cable/internet, electricity, water, heating), } \\
\text { gasoline, personal care (goods and services), } \\
\text { sporting goods/services, hobbies and leisure } \\
\text { equipment, house cleaning (goods/services), } \\
\text { gardening (goods/services), medical expenditures } \\
\text { (supplies/services/prescription drugs), education, } \\
\text { other child spending, entertainment }\end{array}$ \\
\hline $\begin{array}{l}\text { Durable Goods Spending, Excluding Cars } \\
\text { (quarterly frequency) }\end{array}$ & $\begin{array}{l}\text { Refrigerator, stove and/or oven, washer and/or } \\
\text { dryer, dishwasher, television, computer, home } \\
\text { furnishings (furniture, carpeting/rugs, small } \\
\text { appliances) }\end{array}$ \\
\hline $\begin{array}{l}\text { Number of Big-Ticket Items Purchased } \\
\text { (quarterly frequency) }\end{array}$ & $\begin{array}{l}\text { Quantity of big-ticket items purchased (also not } \\
\text { including cars) }\end{array}$ \\
\hline $\begin{array}{l}\text { Discrete Purchase Decisions } \\
\text { (quarterly frequency) }\end{array}$ & $\begin{array}{l}\text { Car purchase; discrete purchase of big-ticket items } \\
\text { listed above (for example, refrigerator), not } \\
\text { including furniture }\end{array}$ \\
\hline
\end{tabular}

In matching the spending data with the expectations data reported in separate survey modules, our intention is to identify, as closely as possible, the expectations held by the individual household at the time its spending decisions were being made. Accordingly, we match the data such that the spending took place during the same calendar month in which the economic expectations were reported, although the

big-ticket spending amounts for a given quarter for an individual. Unfortunately, due to missing months (which would distort quarterly sums), this process contributes only a single additional person-by-quarter observation of bigticket spending for the period between 2011:Q3 and 2012:Q4. 
spending was not reported until early in the following month. ${ }^{9}$ In the case of quarterly durables spending, we identify the calendar quarter in which the spending took place (that is, the three-month period immediately preceding the 10-day period in which the spending survey was completed) and then look, within that quarter, for the earliest-dated expectations survey completed by the same individual household. Because not all respondents completed the expectations survey each month, and because we do not know exactly when, within the quarter, the durables spending took place, the matching between quarterly spending measures and expectations will be less precise than the matching between monthly spending measures and expectations. ${ }^{10}$

\section{Data Description}

Table 1 shows the summary statistics of the key dependent and independent variables for two sets of observations: the person-by-quarter observations of durable goods spending (column 1), and the personby-month observations of nondurable goods spending (column 2). The statistics for time-varying factors represent the unweighted means over person-by-survey observations; the means of demographic characteristics refer to the unique set of individuals represented in the sample, with each person given equal weight. For household income, we show the mean across household-by-survey observations (the “unweighted mean”), as well as the median value of within-household mean income. All dollar values are expressed in 2012 dollars based on the 2012 CPI-U. ${ }^{11}$ Note that these samples consist only of working individuals because these were the only respondents able to report same-job wage-growth expectations as polled in the survey. ${ }^{12}$

For convenience, we will refer to the table's values in column 2, except when otherwise noted, because these are based on a larger number of observations. ${ }^{13}$ Looking at demographic characteristics, the sample respondents are relatively old (the mean age is 56 years), white (94 percent), and well-educated (87 percent have at least some college). ${ }^{14}$ The low percentage of retired individuals (3.5 percent, despite the

\footnotetext{
${ }^{9} \mathrm{~A}$ spending survey must be completed within the first 10 days of a given month (for example, between September 1 and September 10) and poll respondents about their spending during the previous calendar month (August).

${ }^{10}$ When we use expectations formed early in the quarter, there is a chance that these were subsequently revised within the quarter prior to the spending date/s, and when we use expectations formed later in the quarter, there is a chance that these were not formed until after the spending (or some portion of it) took place. Based on the timing of the survey completions, we estimate that roughly 53 percent of the expectations were dated prior to the midpoint of the quarter.

${ }^{11}$ In the case of spending on durable goods, we deflate spending values by the appliances price index.

${ }^{12}$ The regression results should be interpreted as applicable to wage-earning individuals and may not hold among nonwage-earners. We use the restricted sample due to the importance of controlling for wage expectations in the regressions.

${ }^{13}$ The small differences in means across samples are caused by the unbalanced nature of the panel and by the fact that different spending measures refer to different frequencies.

${ }^{14}$ The American Life Panel aims to be a nationally representative sample, but cannot ensure this outcome. The elevated age in our sample reflects the fact that the modules we are using, which also included questions about
} 
high mean age of the sample respondents) reflects the fact that we select for wage earners. As shown in column 2, the sample’s median monthly household income is $\$ 5,047$, implying a median annual household income of $\$ 60,564$, which exceeds the 2012 U.S. median household income of $\$ 51,371$. The average income for any household in any month is $\$ 6,765$. Compared with the household-level median, the higher mean monthly income reflects the facts that (1) the mean income across our sample households exceeds the median income that is consistent with the U.S. distribution, and (2) the sample observes highincome households more frequently than lower-income households. The income figures reflect that all observations for households with mean monthly income greater than $\$ 60,000$ (55 observations) were omitted from the sample.

The mean monthly household spending on nondurable goods (not including mortgage or rental payments, car payments, insurance, or taxes) is roughly $\$ 1,951$. This figure excludes 1,595 householdmonth observations in which spending on nondurables, (including food) was reported as zero, 305 observations pertaining to households reporting mean monthly nondurables spending of $\$ 10,000$ or more, and the top 1 percent of remaining values of household-by-month nondurables spending (22 observations with spending of $\$ 8,494$ or greater). ${ }^{15}$ The mean quarterly spending on large durable goods (not including automobiles or houses) is roughly $\$ 384$ (column 1), but this average includes a substantial number of zero values.

The mean value of expected inflation (density median) at the one-year horizon is roughly 3.4 percent (with minimal variation across samples) and the associated uncertainty (the interquartile range of the inflation forecast distribution) is 2.08 percentage points. For the medium run, defined as inflation expectations at the two- or three-year horizon, the average expected annual inflation rate is greater, at 3.9 percent, and average uncertainty is also greater, at 2.5 percentage points. These values reflect the omission of 141 household-month observations in which short-run expected inflation is 36 percent or greater, and 225 household-month observations with medium-run inflation expectations of 36 percent or greater. (There were no extreme, outlying negative values for expected inflation.) The average expectation for year-ahead real wage growth (the difference between year-ahead expected inflation and year-ahead expected nominal wage growth) is -1.04 percent. Uncertainty surrounding year-ahead (nominal) wage expectations, at roughly 1.5 percentage points, is smaller than the uncertainty attached to year-ahead inflation.

health and well-being, were specifically targeted to an older population. To enhance representativeness, the data can be weighted based on the Current Population Survey. The analysis presented here uses unweighted data due to complications with assigning weights in panel data. For more information on the ALP, see https://mmicdata.rand.org/alp/.

${ }^{15}$ Log-linear models would drop zero spending values anyway. Poisson models, which can accommodate zero spending, are qualitatively robust to these omissions. 
Over the sample period, 44 percent of survey responses indicated that an individual household expected nominal interest rates to increase, 4.5 percent of responses expected interest rates to fall, and the remaining 50.5 percent expected no change in interest rates. Regarding one-year ahead expectations for unemployment, 30 percent of the respondents predicted increases, 23 percent decreases, and the remaining 47 percent expected no change.

Figure 1 shows histograms of monthly and quarterly first differences within households in expected inflation, both for consecutive differences only and for all differences-the latter are successive but may or may not be consecutive. Considering quarter-over-quarter differences, shown in the top two panels, the average difference in expected inflation is 0.011 for consecutive quarters and 0.028 for all quarters. Considering month-over-month differences, the average difference in expected inflation between consecutive months is -0.19 , and the average difference between all months is 0.003 . While the first differences are small on average, the distribution includes significant within-household changes in expectations, even over relatively short periods of time. (The average time between months in the nonconsecutive sample is 3.7 months, with a median difference of three months; the average time between quarters in the nonconsecutive sample is 1.66 quarters, and the median time difference is one quarter.)

Figure 2 shows actual inflation values together with the one-year lagged median values of one-year ahead expected CPI inflation, calculated over our unadjusted sample as well as for the adjusted regression sample. The graph shows that for the regression sample, expected inflation exceeds its realized value in all but four months; for the raw sample, this result holds true for all but one month. Forecasts from the regression sample agree broadly with the raw sample median forecasts, albeit with a few visible exceptions. The raw-sample forecasts extend back to May 2009 but the regression sample does not begin until May 2010, because that is the earliest date for which spending data are also available.

\section{Model Specification}

As is typical of expenditure data, our data on total one-month spending are nonnegative and rightskewed. The durable goods spending data are similar, only more skewed and with the added complication of containing a substantial number of zero values. In dealing with expenditure data, researchers often run an OLS regression of the logarithm of spending on the explanatory variables of interest. Using the log of spending addresses skewness, but requires that zero values either be dropped from the sample or be replaced by a small positive value (or that a small positive constant be added to all spending values). This approach has been shown in many cases to yield biased predictions, for at least two reasons (Nichols 2010). First, if errors are heteroskedastic, spending predictions on the original (non-log) scale will be biased (usually downward), even if the data contains no zero values, unless adjustments that accurately 
account for the heteroskedasticity are applied. This bias is termed the "retransformation problem" (see, for example, Manning 1998 and Manning and Mullahy 2001). Second, when there are a significant number of zero values, dropping these or translating the data may bias the coefficient estimates for a variety of reasons-for example, if the observations involving zero spending are starkly different from those that involve very low but positive spending, or if the zero values actually represent missing values.

An extensive literature on health expenditures suggests numerous options for modeling such data, including two-part models in which the first part models the discrete choice to spend a non-zero amount, and the second part models continuous non-zero spending, and generalized linear models (GLM), which allow for nonlinear transformations of the dependent variable (such as logs), yet do not suffer from the retransformation problem and do not require excluding zero values because these models predict the (log of) expected spending rather than the (log) of actual spending. To select an appropriate model, we chose a list of candidates based on suggestions from the literature and compared their performance using splitsample cross-validation (Nichols 2010). ${ }^{16,17}$ Our candidate models include a standard OLS model of raw expenditures, an OLS model of the log of expenditures (dropping zero values), and a GLM model of the $\log$ of expected expenditures with a Poisson error distribution. ${ }^{18}$ Among models of both durable goods spending and nondurable goods spending, the respective Poisson models perform best and therefore will be considered the "preferred" models. In subsequent results tables, for comparison purposes and to give a sense of robustness, we show the results for all candidate models. However, in the discussion, we will highlight the results of the Poisson models.

For each model type, we estimate versions with and without controls for unobserved heterogeneity at the individual household level in order to show the extent to which such heterogeneity drives the relationships between the variables. In theory, the hypothesized relationship should hold at the level of within-individual changes and not merely be an artifact of aggregation. In the case of the OLS model of raw (non-logged) spending, we adopt a first-difference model as an alternative to using fixed effects; in the log-linear (OLS) model, we use a fixed-effects estimator, and in the Poisson models, we use Stata's

\footnotetext{
${ }^{16}$ It has been shown that for expenditure data, standard measures of goodness of fit tend to be misleading as a result of overfitting and because of the aforementioned "retransformation problem."

${ }^{17}$ This method entails fitting a given model on a randomly selected half-sample of person-year observations, using the fit to predict outcomes for the remaining half-sample, and computing the mean squared forecast error. We repeat this process 50 times for each model and designate the "preferred" model as the one with the lowest average mean squared forecast error across the iterations.

${ }^{18}$ The GLM models we employ are equivalent to standard Poisson regressions. GLM in Stata performs maximumlikelihood estimation using the Newton-Raphson method, with robust standard errors. (For Poisson models with fixed effects, we employ xtpoisson in Stata, which uses conditional maximum-likelihood.) The Poisson distributional family was selected among GLM models using a Park's test. Due to the high number of zero values for durable-goods spending, we also tested a "zero-inflated" Poisson model, which is an example of a two-part model. However, this model did not outperform the standard Poisson model in the cross-validation test, involves additional complexity in interpreting marginal effects, and does not as readily accommodate addition of fixed effects for individuals.
} 
xtpoisson command. As described above, we observe modest but statistically significant withinhousehold variation in expected inflation over time during the sample.

A test suggested by Wooldridge (2002) and executed in Stata following Drukker (2003) indicates that the time-varying disturbances on individual spending, for nondurables at the monthly frequency and for our quarterly durables spending measure (but not for counts of durable goods), exhibit serial correlation. Given this finding, a first-difference estimator will be more efficient than a fixed-effects estimator. However, the statistical significance of most coefficient estimates does not differ between the two approaches, even when using robust standard errors in each case. In addition, we lose large numbers of observations in first-difference models if we impose the condition that differences be calculated using consecutive months (or consecutive quarters) of data. In order to achieve a sufficient number of observations, we do not impose this constraint, an allowance that introduces measurement error in the first differences. In sum, given the properties of our data there are both advantages and drawbacks to adopting a first-difference model, and therefore this specification is not clearly superior to a fixed-effects model.

In all models, we cluster the standard errors at the level of the individual household. In addition, we include observations from individual households only if we observe that same household at least four times, whether in each of four months in the case of nondurables spending or four quarters in the case of durables spending. This exclusion does not reduce the number of observations dramatically and results in a modest increase in the precision of the estimates. Most qualitative results are robust to relaxing this restriction. All models include time dummies; in the first-difference models, they represent differences between time dummies, whether consecutive or not depending on the difference involved in the given observation.

\section{Main Results}

Table 2 shows the regression results of various models of quarterly spending on big-ticket consumer durables, including refrigerators, stoves, ovens, washers, dryers, computers, and televisions. In all the models represented in Table 2, we use the short-run (one-year ahead) inflation expectation and its associated uncertainty. In this and in all subsequent regression tables, the coefficients in the Poisson and log-linear (OLS) models represent fractional changes (or, if multiplied by 100, percentage changes) in household spending (at the given time frequency) for a unit change in the explanatory variable. ${ }^{19}$ For expected inflation, inflation uncertainty, expected wage growth, and wage growth uncertainty, a unit change represents one percentage point; for expected movements in unemployment and interest rates (and

${ }^{19}$ In the GLM models marginal effects represent population-averaged marginal effects rather than the marginal effects calculated at the respective averages of the independent variables. 
discrete demographic factors), a coefficient represents the effect of changing the value of the dummy variable from zero to one. For household income, we convert to logs in the Poisson and log-linear models, so for these models the respective coefficients on income represent elasticities. In the standard OLS models, all the coefficients represent dollar changes in spending for a unit change in the explanatory variable.

In the preferred Poisson specifications (columns 1 and 2), the respective coefficients on expected inflation are negative and, in the model with fixed effects, marginally significant. The estimate in the fixed-effects model means that quarterly durable goods spending falls by about 8 percent on average (or about \$31 at mean quarterly spending of roughly \$384) for a 1 percentage point increase in expected inflation. The latter coefficient $(-0.08)$ has a greater absolute value than the coefficient in the model that omits fixed effects $(-0.02)$, although the confidence intervals of these estimates overlap. ${ }^{20}$ This finding suggests that, on average, households with higher inflation expectations tended to have greater average spending on durable goods. As a result, models that fail to control for household heterogeneity may contain an upward bias on the estimated effect of inflation expectations on durable-goods spending.

Coefficients in the log-linear models (columns 3 and 4) are also negative and have magnitudes similar to the corresponding estimates from the Poisson models, although neither coefficient is statistically significant. Again the fixed-effects estimate has a larger magnitude than the estimate that does not control for fixed differences between households. The smaller sample sizes in the log-linear models reflect the fact that all quarterly household observations of zero spending are dropped of necessity (not just for those households that always report spending nothing on durables), although these omissions do not appear to make a significant difference in the effects of expected inflation on household spending decisions.

In both the OLS models (columns 5 and 6), the coefficients on expected inflation are negative, with a larger magnitude in the first difference model (column 6, but neither estimate is statistically significant. The effect in the first-difference model, estimating a decline of roughly $\$ 20$ in current-quarter durables spending for a 1 percentage point increase in expected inflation, is roughly two-thirds the size of the effect from the corresponding (and preferred) Poisson model depicted in column 2.

The estimated effects of individual inflation uncertainty, measured as the interquartile range of the individual inflation-forecast density function, are insignificant across all models in Table 2. In the models that control for fixed effects, perhaps counterintuitively, the point estimates are consistently positive and/or greater than the coefficients from models without fixed effects. These results suggest that

\footnotetext{
${ }^{20}$ In the Poisson model with fixed effects, households with uniformly zero values for quarterly durable spending are omitted from the sample because the conditional likelihood function is not defined for these households. Therefore, the comparison between columns 1 and 2 does not purely hold, ceteris paribus.
} 
households may spend more on durable goods as their inflation forecast becomes less certain, but the estimated effects are economically modest and, as stated above, statistically insignificant.

The survey asks whether the respondent expects "interest rates for borrowing money" to increase, decrease, or stay the same one year in the future. Our presumption is that the responses reflect subjects' expectations of nominal, as opposed to real, interest rates, consistent with the interpretation of the survey authors (Hurd and Rohwedder 2013). Holding expected inflation constant, changes in expected nominal rates imply changes in expected real rates. In contrast, changes in expected (period-ahead) inflation imply changes in the current real interest rate, defined (as in the Fisher equation) as the real (period-ahead) return on current savings (or the real one-period cost of current borrowing), equivalent to the difference between the current nominal rate and expected inflation.

The predicted signs on the nominal rate expectations depend on assumptions about the characteristics of household debt, such as the period over which it will be paid off, whether the interest rate is fixed or variable, the costs of debt refinance (on fixed-rate debt), and the consumer's rate of time preference. Given the goods under consideration here (televisions and other somewhat costly durables likely financed with credit cards and paid off over the relatively short term), there is reason to expect current-quarter interest-sensitive purchases to be delayed when borrowing rates are expected to fall, relative to a situation in which rates are expected to stay the same. Conversely, current-quarter durable-goods purchases are expected to rise when future borrowing rates are expected to rise, as households plan to take advantage of (or perhaps lock in) lower current interest rates. ${ }^{21}$

In all models except the first-difference model, an expectation that interest rates will rise (rather than stay the same) is associated with greater current-quarter spending on durable goods. The effects vary in size from a roughly 12 percent increase in the Poisson models (with or without fixed effects) to a \$107 increase in the OLS model (column 5), but none is statistically significant. In the first-difference model, the coefficient becomes negative, although the standard error of the latter estimate implies that positive effects are also possible within one standard deviation.

The coefficients on "interest rates expected to decrease" are negative in all but one case and are marginally significant in the OLS and first-difference models. In the first-difference model, the effect is substantial, implying a decline in durable goods spending of \$248 in the current quarter, representing roughly two-thirds of average quarterly durables spending in the sample. Although the estimate is insignificant, the Poisson model with fixed effects also predicts a large (44 percent) decline in current durable-goods spending with an expected decline in interest rates, all else equal. While the effects

\footnotetext{
${ }^{21}$ Since the passage of the Credit CARD Act of 2009, variable-rate credit cards have become the norm rather than the exception.
} 
estimated here are mostly statistically insignificant, Bachman, Berg, and Sims (2012) observe that nominal interest rate expectations have statistically significant effects that are qualitatively similar to ours.

The effects of an expected (discrete) increase in the unemployment rate are mixed across the models and in all cases are statistically insignificant. While we might expect households to reduce spending when they expect unemployment to rise, the strength of the precautionary motive likely depends on the extent to which individuals believe they will be personally affected by higher unemployment. ${ }^{22}$ The effects of an expected (discrete) decline in unemployment are all positive in sign. The coefficient is large and statistically significant at the 1 percent level in the preferred Poisson model with fixed effects, implying a 38 percent increase (or \$146) in current-quarter durables spending, roughly consistent with the (imprecisely) estimated effect of $\$ 127$ in the first-difference model. Because the individuals in the household sample are employed, an expected decline in unemployment could benefit such individuals by lowering their risk of becoming unemployed (rather than raising their risk of moving into employment). This expectation variable might also proxy for an expected general improvement in the economy, which could benefit employed individuals in the form of higher wealth, held for example in stocks, retirement accounts that include stocks, and/or home equity. Any expected benefit to wages is captured in the wagegrowth expectation variable. These effects are net of any common, sample-wide changes in macroeconomic conditions and/or expectations that are captured by the time dummies.

The effects of current (log) household income on durables spending are positive in all models (except the first-difference model) and are larger and more precisely estimated in models without fixed effects. (In the Poisson and log-OLS models, where the dependent variables refer to log spending, we use log income on the right-hand-side. In the OLS and first-difference models, where the dependent variables refer to raw spending, we use raw income on the right-hand-side.) These results indicate that, in the crosssection, households with higher average income consistently spend more, amounting to a 0.6 percent increase in spending for each 1 percent increase in income in the Poisson model without fixed effects (column 1). At the same time, individual households - in line with the permanent income hypothesisrespond comparatively weakly to changes in income over time, as indicated by smaller coefficient estimate (0.3 percent) in the Poisson model with fixed effects. The effects of expected (own) real wage growth-an expectation that pertains to the survey respondent and not the entire household, conditional on his/her staying in the same job- carry (unexpected) negative signs across the board, and the coefficient is marginally significant (only) in the preferred model, the Poisson model with fixed effects (column 2), indicating that a 1 percentage point increase in expected real wage growth results in a 4

\footnotetext{
${ }^{22} \mathrm{~A}$ time-limited survey module asked individuals about the probability they would still be at their current job within one year. However, those answering "no" include (in unknown proportions) people expecting to change jobs as well as people expecting to become unemployed. The survey asked about the probability of job loss only for a very limited time, such that including this variable unduly restricts the sample size.
} 
percent (roughly \$16) decline in quarterly durables. While unexpected, this effect is modest and its significance is not robust across models. Uncertainty over future (nominal) wage growth has mostly negative coefficients in spending, as expected, although the estimate in the preferred model (column 2) is small and insignificant, and the remaining estimates are marginally significant at best.

Looking at the effects of demographic factors (included in the models that lack fixed effects), greater age is associated with greater spending, but the effect is significant only in the log-linear model. The effects of being white, female, and having some college education are inconsistent across the models and are never significant. Consistent with economic intuition and prior evidence, being retired is associated with less spending on durable goods, and the association is both statistically and economically significant in the OLS model. ${ }^{23}$

Table 3 shows the results from additional regressions of quarterly spending on durable goods. In these models, we substitute the medium-run expectation for inflation two-to-three years in the future and its associated uncertainty for the one-year ahead expectations (and uncertainty) included in the results summarized in Table 2. Otherwise the explanatory variables are the same as in Table 2. (Expectations of wage growth, interest rate changes, and unemployment rate changes are solicited only for the one-year ahead horizon.) The coefficients on medium-run inflation expectations are again negative in all models. The magnitudes of these coefficients are smaller than those of the corresponding coefficients on the shortrun inflation expectation, and none is statistically significant. These results suggest that the durable goods in question might be financed over a relatively short period, such that inflation two-to-three years ahead might have little impact on the real financing costs of goods purchased in the present. Alternatively, or in addition, longer-term inflation projections are less certain on average (as seen in Table 1), and so may carry less force.

Although not statistically significant, the coefficient on medium-run inflation uncertainty is negative in the preferred model (and in all but one of the alternative models), a reversal from the sign on short-run inflation uncertainty. It is not obvious why the effect of inflation uncertainty would change signs between the short run and the medium run. One possibility is that the impact of inflation uncertainty depends on whether it is driven by upside risks or downside risks, which may vary (by chance) at different time horizons. However, the standard error of the coefficient on short-run inflation uncertainty (from Table 2) was large enough to admit negative values in the 95-percent confidence interval.

The remaining variables are unchanged from the models in Table 2 and, as expected, the estimated coefficients are similar both qualitatively and quantitatively to those seen previously. The coefficient on

\footnotetext{
${ }^{23}$ These individuals reported being retired as well as being employed. We retained them to maximize sample size and representativeness. One possibility is that these individuals have retired from a primary or career job and are engaged in part-time work or odd jobs.
} 
"interest rates expected to decrease" in the first-difference model is significant at the 5 percent level in this model, up from 10 percent significance in the corresponding result from Table 2. The effect implies that a household will lower its current-quarter spending on durables by $\$ 277.50$ when it expects interest rates to fall, compared with its spending under static rate expectations-again supporting the notion that the expected interest rate decline gives consumers an incentive to delay purchases of durable goods.

Table 4 shows the results of the two Poisson models in which the dependent variable is the total number of durable goods purchased by the household in a given quarter, rather than the amount of money spent on these goods. These models are estimated based on the possibility that the counts margin of demand for durables responds differently than the spending margin, in view of the discrete nature of such purchases and the wide range of prices one might pay for such goods (such as refrigerators and ranges). These models also offer a measure of real consumption of durable goods that is not sensitive to the choice of deflator. With a counts variable, the Poisson models are the natural choice, and we therefore exclude other specifications.

The first two columns of Table 4 show the results for models that include short-run inflation expectations and its associated uncertainty, first without controls for individual fixed effects and then including such controls (again using Stata's xtpoisson command). The remaining columns show the same models but substitute the medium-run inflation expectation and its associated uncertainty for the short-run inflation variables. The coefficients represent fractional changes in the number of durable goods purchased for a unit change in the given explanatory variable.

The effects of expected inflation at either time horizon are small, mostly negative, and statistically insignificant. The coefficient on the medium-run inflation expectation is positive in the model without fixed effects, but is very small and not significant. The effects of inflation uncertainty are also insignificant, and have small negative magnitudes in models that include fixed effects. An expected increase in interest rates has significant positive effects in models that omit fixed effects, but the effects become smaller and insignificant when fixed effects are included. The effects of an expected interest rate decline are negative in sign and, while economically meaningful in models with fixed effects, are statistically insignificant. While these coefficients are mostly consistent, at least qualitatively, with the effects of interest rate expectations on total spending on durable goods, the reduced magnitude and significance suggests that the number of goods purchased is less sensitive to rate expectations than is the dollar amount spent on the goods.

For the remaining variables, none of the coefficient estimates achieve more than marginal significance. Considering the models with fixed effects, the respective signs of the coefficients are largely consistent with those from the spending models. One exception, more consistent with intuition, is that an expected increase in unemployment is negatively associated with the number of durable goods purchased. The 
effects are marginally significant and economically meaningful in the models without fixed effects (columns 1 and 3), but the coefficients fall in magnitude by roughly half and lose significance when the fixed effects are included.

Table 5 shows the results of regressions in which the dependent variable is monthly household spending on nondurable goods, including clothing, food, utilities, gasoline, personal care goods and services, sporting goods and services (such as bicycles and gym memberships), medical expenditures, spending on hobbies and leisure (such as books and camping gear), and other items listed in Table $\mathrm{C}$ on page $9 .{ }^{24}$ For this dependent variable, the Poisson models again are the preferred specification, but the predictive power (over the sample omitting zero spending values) is very close between these models and the log-linear model. The sample sizes are larger than in Tables 2-4 because the data are at a monthly rather than quarterly frequency, and the sample size no longer drops dramatically in the log-linear models because there are very few zero values for spending on nondurable goods.

In the Poisson model with fixed effects (column 2), the coefficient on short-run expected inflation is now positive and statistically significant at the 5 percent level, but small in economic terms-a 1 percentage point increase in expected inflation raises current-month spending on nondurable items by 1.1 percent, or \$21.46 at the sample-average monthly spending level. The estimated effects are similar in the log-linear model with fixed effects (column 4) and in the first-difference model, where each of these coefficient estimates is significant at the 10 percent level. No significant effects of inflation expectations on spending are observed in models that do not control for household heterogeneity (columns 1, 3, and 5). Inflation uncertainty appears to have significant positive effects on spending in these same models, but the effects fall effectively to zero and become insignificant when fixed effects (or first differences) are included.

Income effects are highly significant in each of the first four columns in Table 5. As with spending on durable goods, including fixed effects reduces the magnitude of income effects considerably. Also, as we would expect, this spending measure is less income-elastic than the spending measure for durable goods. In the Poisson model with fixed effects, spending on nondurable goods increases when interest rates are expected to rise; the effect is highly significant but is more modest in size (there is just a 5.4 percent increase in spending for a discrete change in the interest rate expectation) than the corresponding effect for durable goods (although the latter estimate was not statistically significant). The effects of an expected interest rate decrease are mixed and never significant for spending on nondurable goods. An expected increase in unemployment is negatively associated with purchases of nondurables, but the effects are very

\footnotetext{
${ }^{24}$ Some of the items captured in this spending variable are highly durable, such as bicycles and boats (included in the sports category) and camping gear (in the hobbies/leisure category). However, the durable items are bundled into categories that also contain nondurable items, including services. When we construct the spending values omitting the sports and leisure categories, the results are robust.
} 
small and insignificant in the preferred model (and also in the log-linear model with fixed effects). Expected real wage growth has positive coefficients across the board, but the effects are all very small and, in the preferred model, not significant. Whites and women appear to spend substantially more than nonwhites and men, respectively, although these effects are in most cases imprecisely estimated. Having some college predicts higher spending levels, a difference which is large (\$463 in current-month spending) and highly significant in the OLS model (column 5). In the same model, retirement has a significant negative effect on spending, but the corresponding effect is small, positive, and insignificant in the preferred model.

In Table 6, we observe that medium-run inflation expectations exert no significant effects on spending for nondurable goods, although the coefficient estimates all have positive signs. The coefficients on medium-run inflation uncertainty (as for short-run inflation uncertainty) again indicate a positive and statistically significant correlation in the cross-section that becomes negative and insignificant in the fixed-effects models. The estimated effects of the remaining variables are largely unchanged from Table 5.

Note that the models in Tables 5 and 6 have generally greater explanatory power (or higher joint significance) than their respective counterparts for durable goods (displayed in Tables 2 and 3). The most likely reason for the difference lies in the presence of the large number of zero values for durable goods spending. This owes to the lumpy nature of spending on such goods, combined with the fact that we have fewer observations per household (and fewer overall households) with which to identify effects because this survey was fielded at a quarterly, rather than a monthly, frequency.

\section{Inflation Expectations, Spending, and Household Balance Sheets}

There are conflicting predictions concerning how the composition of a household's balance sheet might alter the relationship between its inflation expectations and spending. For example, Bachmann, Berg, and Sims (2012), among others, make the point that debtors should be more likely than creditors to increase spending in response to an increase in their inflation expectations-because higher expected inflation boosts expected real wealth among debtors. While higher expected inflation also means lower expected real wealth for creditors, debtors are presumed to have a higher marginal propensity to spend out of wealth than creditors. However, Bachmann, Berg, and Sims do not find that proxies for debtor status, such as being younger than 48 years of age or having a low income, are associated with increased sensitivity (meaning greater than the essentially zero sensitivity found on average) of spending to inflation expectations. 
In contrast, Ichiue and Nishiguchi (2013) argue that current spending by asset holders should be more sensitive to inflation expectations than is spending by individuals with lower net worth; this is because asset holders are likely to have greater access to credit with which to finance current consumption. With respect to the prior argument that households with lower net worth may have a higher desired marginal propensity to consume, it is possible that liquidity constraints might prevent them from achieving their desired consumption levels. Ichiue and Nishiguchi find that current spending among asset holders does exhibit a stronger (positive) response to expected inflation, where an asset-holder is defined as someone who reported holding stocks, bonds, savings accounts, and/or real estate.

Our data indicate whether the individual reporting for the entire household owns a home, has a retirement account, and/or owns stocks. We also observe whether homeowners have a mortgage and divide homeowners into two groups, those who carry a mortgage and those who own the home outright, because inflation expectations could have different effects depending on the mechanism through which it affects spending. If debt devaluation is important, then mortgage holders might be particularly sensitive to higher expected inflation, whereas if real estate wealth facilitates borrowing for current consumption, those who own their homes outright might exhibit a stronger spending response to higher expected inflation than those with less home equity. (These effects are not mutually exclusive, of course.)

With multiple observations per individual household, we observe some changes in the asset-related variables over time within households, although such variation is limited. ${ }^{25}$ Tables 7 and 8 show the results for Poisson models of spending (with and without fixed effects) on durable goods and nondurable goods, respectively, in which we include a dummy (or dummies) for a given asset-related variable as well as an interaction term between the given dummy (or dummies) and the household's short-run median inflation expectation. The tables show only the coefficients of interest: the main coefficient on expected inflation-which measures the impact of expected inflation for the omitted category in a given regression - the stand-alone dummy (or dummies), and the interaction term (or terms) between a particular dummy variable and expected inflation.

As seen in Table 9, pertaining to quarterly spending on durable goods, the coefficient on inflation expectations is negative and insignificant in both columns, where these effects pertain to the default category of individuals who have a retirement account. The interactions between inflation expectations and "no retirement account" are never significant, although they carry positive signs in both models (with and without fixed effects). Turning to Table 10 (column 1), we find that, among those with a retirement account, the effect of inflation expectations on monthly nondurable goods spending is negative and

\footnotetext{
${ }^{25}$ The fixed effects models here do not require within-individual variation in, say, homeowner status; with no such variation, the model would identify the effects of inflation expectations for a particular category using withinindividual variation in inflation expectations among the individuals in that category.
} 
insignificant; however, the coefficient on the interaction term indicates that, among individuals (or observations) that do not have a retirement account, current-month spending on nondurables responds more positively to an increase in inflation expectations than it does for the default group. The stand-alone dummy indicates that not having a retirement account is associated with significantly lower spending (by 48 percent on average). With fixed effects included, the effect of inflation expectations on spending among those with a retirement account is roughly equivalent to the coefficient estimated over the entire sample (seen in Table 2, column 2), but is marginally less significant. The interaction with not having a retirement account falls essentially to zero (0.0033) and becomes statistically insignificant. The crosssection results are suggestive of a stronger response among nonholders of retirement accounts in the case of nondurable goods, but we cannot be certain that this effect does not owe to other, unobserved differences among the members of this group that predict both inflation expectations and spending on nondurable goods.

Concerning stockholdings, we observe no significant differences in the impact of inflation expectations on durable-goods spending that depends on whether an individual reports owning stocks (Table 9). When the observations are separated on this basis, neither group displays a significant spending response to inflation expectations, and in the model with fixed effects, both the main coefficient on inflation expectations (pertaining to the default group of stockholders) and the interaction term (nonstockholders) carry negative signs. In the model of monthly nondurables spending (Table 10), again we observe no significant effects of inflation expectations on spending for either stockholders or nonstockholders, and estimated coefficients are positive and close to zero in the models with fixed effects. In the model without fixed effects, we find that nonstockholders spend roughly 19 percent less per month on nondurable goods than stockholders do.

Concerning homeownership and mortgage status, the results are mixed. For durable goods (Table 9), in the model without fixed effects we observe that homeowners, both with and without a mortgage, spend significantly more on durable goods than nonhomeowners do. The effect of inflation expectations on durables spending is negative and insignificant for nonhomeowners; the interaction coefficient is negative and insignificant for homeowners with mortgages and positive and insignificant for homeowners without mortgages. With fixed effects, the main effect of inflation expectations becomes positive and the interaction coefficients become negative, but all of these estimates are insignificant. For nondurable goods, the effect of inflation expectations on spending for nonhomeowners is small, negative, and statistically insignificant. Homeowners without a mortgage appear to exhibit greater sensitivity to inflation expectations (compared with nonhomeowners), based on positive interaction coefficients in both the Poisson models (with and without fixed effects). In the model with fixed effects, the interaction coefficient is statistically significant and this result suggests that, conditional on owning a home outright, 
higher expected inflation may lead to greater spending on nondurable goods. This group may be driving the positive, unconditional coefficient on inflation expectations observed in models of nondurable goods spending.

Taken together, the results reported in Tables 7 and 8 do not offer much evidence that inflation expectations have different effects on spending decisions made by households who own assets such as stocks or retirement accounts and households who do not own such assets. However, in the case of nondurable goods spending, there is some evidence that homeowners who are not mortgagees respond more strongly (positively on net) to expected inflation than do nonhomeowners (renters). Although we control (linearly) for age, owning a home outright may proxy for older age, which according to some hypotheses (see, for example, Malmendier and Nagel 2013) may indicate an increased salience of inflation based on these individuals' having experienced periods of elevated inflation in their adult lifetimes. Alternatively, their greater response may reflect an ability to borrow against home equity to finance higher current consumption, although it is not clear why this should apply to spending on nondurable goods and not to spending on durable goods.

\section{Discussion: Making Sense of Counterintuitive Results}

To determine what might be driving the different effects of inflation expectations on durable-goods spending versus spending on nondurable goods, it is helpful to estimate models based on disaggregated spending measures for each separate spending category we observe. Table 9 shows, for each such spending category (or specific good, in the case of appliances), the coefficient on the short-run inflation expectation (and its associated p-value) from a Poisson model (including fixed effects) of spending. The categories are divided between durables and nondurables, as indicated in the table. Among "nondurable" goods, clothing carries a positive and statistically significant coefficient that implies that a 1 percentage point increase in expected short-run inflation increases spending on clothing by 3 percent on average, a magnitude greater than the coefficient on our bundled measure of nondurables spending.

Because clothing is durable to some extent, and apparel purchases can be substituted across time to a greater extent than, for example, food purchases, this result is in accord with the main theoretical predictions. Spending on clothes represents about 6 percent of overall nondurables spending. To the extent that clothing spending is driving the overall effect on nondurable goods spending, the positive coefficient is less surprising. However, spending on water (as a utility) and house-cleaning services also respond positively even though we would expect demand for these items to be inelastic with respect to the real interest rate. If these latter results represent statistical flukes, and if we strip clothing out of the nondurables spending measure, we should be cautious in generalizing from our results to broader 
measures of overall consumer spending on nondurable goods. Food spending, for example, does not respond positively to inflation expectations.

Considering the individual items in our durable goods spending measure, refrigerator purchases (which typically represent the price of a single refrigerator purchased in the quarter) declines sharply with expected inflation and the effect is highly statistically significant. Spending on furniture also declines, but less sharply and with lower statistical significance. Only spending on computers carries a positive coefficient, and it is imprecisely estimated. These results indicate that spending patterns for refrigerators (and possibly also for furniture and dishwashers) are driving the negative coefficient on inflation expectations in the durable-goods spending regressions.

Figure 3 shows the relative price inflation for major appliances, automobiles, clothing, and an index of all durable goods. A given series is calculated as the difference between the year-over-year percent change in the price index for the specific good (for example, the appliance price index) and the year-overyear percentage change in the overall CPI, at a monthly frequency. Values below zero indicate that the specific good's price fell in relation to overall inflation and values above zero indicate relative price increases for the specific good. As seen in Figure 3, major appliances experienced relative price declines (and even absolute price declines) during most of our sample period, declines which stayed at or below -3 percent for a period of 14 consecutive months and which reached -6 percent or less in each of three separate months . If price expectations for appliances were driving purchase and spending decisions for these goods, and since appliance prices were falling in relative or absolute terms for extended periods of our sample, we might have obtained a spurious negative (if weak) association between expected overall inflation and durable goods spending. Note that the overall durable-goods price index also fell in relative terms during most of the sample, although not as sharply on average as the appliance price index. Complicating the story, the relative price of clothing was also declining during most of our sample period-albeit not as sharply as the relative price of appliances-and despite this decline, clothing expenditures responded positively to overall inflation expectations.

There is another potential explanation for the durable goods results. Although we control for time fixed effects, the results may reflect the overall declines in spending on home-related goods (appliances and furniture, for instance) that occurred during the Great Recession as part of the housing bust. Within this context, it is possible that some households in our sample reduced their home-goods expenditures significantly (for example, in response to negative shocks to their home equity) at the same time as they raised their inflation expectations for unrelated reasons, perhaps in response to monetary policy stimulus. The negative demand shock to appliances presumably contributed to their price declines over the sample period. 
Looking at discrete purchase decisions for durable goods (Table 10, including cars, we find that the likelihood of buying a car increases by 17 percent (over a baseline car purchase chance for the individual) for a 1 percentage point increase in inflation, where the coefficient has a p-value of 0.06 . The signs on the remaining purchase decisions are mixed between negative and positive values, but none is statistically significant. Since cars carry a larger price tag than, for example, refrigerators, and are typically paid off over a longer term, the real interest rate may be more salient for car purchase decisions than for buying appliances. In addition, as seen in Figure 3, during most of our sample period car price inflation diverged less sharply from overall CPI inflation than did appliance price inflation. These mixed results suggest that, when considering whether to purchase cars or large appliances, a consumer might factor in expected future price changes for the specific good in question, rather than overall price inflation, where these factors may diverge in any given period.

It is then important to determine whether our respondents actually expected their incomes to rise in step with prices. Even though we control for expected real wage growth, this control may be subject to measurement error, because it combines separately reported expectations of nominal wage growth and inflation expectations. In a simple regression of year-ahead individual nominal wage growth expectations against year-ahead individual inflation expectations controlling for individual fixed effects (results not shown) we find that a 1 percentage point increase in expected inflation is associated with a 0.13 percentage point increase in expected nominal wage growth over the same time horizon. This result is significant at the 5 percent level and represents a significant erosion of real wage growth. Across all person-by-survey observations in our main regression sample, the mean value of expected real wage growth is -1.4 percent, and the median value is -1.1 percent. For the survey question, "what is the percent chance that, 12 months from now, your earnings would have increased faster than prices in general,” the median response is 10 percent, the mean is 21 percent and the 75th percentile response is just 40 percent. These data agree with the survey data in Shiller (1997), in which he finds that individuals appear to dislike inflation primarily because of the perceived negative impact that inflation will exert on their "standard of living."

In fact, between 2010:Q1 and 2013:Q1, the median real weekly wage increased on a year-over-year basis in only a single quarter, 2012:Q2, and then by only 0.3 percent. Otherwise real wage growth was zero or negative, falling as low as -2.05 percent in 2011:Q4. The average real wage growth for this period was roughly -1 percent, which aligns closely with -1.1 percent, the median expectation in our sample cited just above. We select the period from 2010:Q1 through 2013:Q1 because it overlaps with the realized values of real wage growth that were forecast during our regression sample period.

\section{Summary and Policy Implications}


Taken together, our findings offer only very limited support for the hypothesis that higher inflation expectations may boost current consumer spending. In the preferred model, short-run expected inflation boosts an individual's current-month spending on nondurable goods by 1.1 percent, or about $\$ 21$ on average. While this result is fairly robust, spending on goods for which demand is expected to be particularly sensitive to inflation expectations-big-ticket durable goods-does not increase with expected inflation, and may actually decline, nor does the number of such goods purchased respond as predicted. Looking at discrete purchase decisions for individual durable goods, only car purchases respond positively to higher expected inflation. While there are conflicting predictions relating to how a household's net worth should affect its response to inflation expectations, we do not observe stark or consistent differences in the response of spending to inflation expectations between different households grouped on the basis of factors such as owning stocks, having a retirement account, or owning a home.

There are a number of reasons why we might be observing weakly negative effects of inflation expectations on durable goods purchases and positive effects on nondurable goods purchases. As discussed above, despite being a semi-durable good, clothing was included in the nondurables category. Regarding demand for durable goods, we observe that price inflation for major appliances fell below overall price inflation (or was negative in absolute terms) between late 2008 and late 2011, a time that covers a substantial portion of our sample period. If price expectations for durables were driving purchase and spending decisions for these goods, and since price movements for durables often fell below overall inflation, we might have obtained a spurious negative, if weak, association between expected inflation and durable goods spending.

In general, there are a number of reasons why the effects of inflation expectations on spending may be less economically significant and less robust than theory (and participants in some recent policy debates) might expect. While some of these reasons, such as nominal rate illusion, were discussed by Bachmann, Berg, and Sims (2012), a prime culprit not much discussed in the existing literature concerns income expectations. While the expected real opportunity cost of current consumption, figured in terms of foregone future consumption, falls as expected inflation rises regardless of future income, higher expected inflation may reduce expected real income unless income is fully and continuously indexed to inflation, thus putting a damper on consumption in both the present and the future. In an account of how Roosevelt brought about the end of the Great Depression, Eggertsson (2008) argues that a commitment to an inflationary monetary policy was coupled with a commitment to an expansionary fiscal policy. By creating expectations of both higher future inflation and higher future income, these policies reinforced each other in stimulating current demand.

Of course, in the aggregate, increases in the overall price level (holding real output constant) must show up as increases in nominal income, however it is distributed. Although consumers might be 
expected to index their nominal wage growth expectations to their inflation expectations, the consumers in our survey, on average, expected their wage growth to fall well short of inflation growth. This disconnect need not be seen as irrational because, as has been the case in recent years, real wage growth may lag inflation for extended periods. Under such circumstances, other income sources (such as stock dividends) must reflect inflation, but for many consumers wages and salary represent the bulk of their income. Even among consumers who expect their wage growth to eventually catch up to inflation, the relevance of the real borrowing costs channel will depend on how quickly their wages catch up in relation to the borrowing period.

While our results indicate that inflation expectations may be associated with weakly higher spending when expected real wage growth is held constant, policymakers cannot hold expected real wage growth constant. Therefore, the unconditional policy-relevant effect that expected inflation exerts on consumer spending may be even weaker than the effects observed in our models. In addition, we find that movements in the prices of specific goods, such as large appliances, may depart significantly from overall price inflation for extended periods, and that these specific price movements may matter more than overall inflation (again, especially if wage growth falls behind inflation). In sum, our results suggest that the broader economic context within which an increase in expected inflation occurs will likely be critical for determining how a monetary policy that seeks to lower real interest rates by raising inflation expectations ultimately affects consumer spending. 


\section{References}

Appelbaum, Binyamin. 2013. “In Fed and Out, Many Now Think Inflation Helps.” New York Times, October 26.

Bachmann, Ruediger, Tim O. Berg, and Eric R. Sims. 2012. "Inflation Expectations and Readiness to Spend: Cross-Sectional Evidence.” Working Paper No. 17958. Cambridge, MA: National Bureau of Economic Research.

Barattieri, Alessandro, Susanto Basu, and Peter Gottschalk. 2010., "Some Evidence on the Importance of Sticky Wages.” Working Paper No. 16130. Cambridge, MA: National Bureau of Economic Research.

Burke, Mary. A., and Michael Manz. 2011. "Economic Literacy and Inflation Expectations: Evidence from a Laboratory Experiment.” Public Policy Discussion Paper (11/8). Boston: Federal Reserve Bank of Boston. (Paper also forthcoming in the Journal of Money, Credit and Banking.)

Bruine de Bruin, Wandi, Charles F. Manski, Giorgio Topa, and Wilbert van der Klaauw. 2011. "Measuring Consumer Uncertainty about Future Inflation.” Journal of Applied Econometrics 26(3): 454-478.

Christiano, Lawrence J., Martin Eichenbaum, and Charles L. Evans. 2005. "Nominal Rigidities and the Dynamic Effects of a Shock to Monetary Policy.” Journal of Political Economy 113(1): 1-45.

Drukker, David M. 2003. “Testing for Serial Correlation in Linear Panel-Data Models,” The Stata Journal 3(2): 168-177

Eggertsson, Gauti B. 2008. "Great Expectations and the End of the Depression.” American Economic Review 98(4): 1476-1516.

Eggertsson, Gauti B. and Michael Woodford. 2003. “The Zero Bound on Interest Rates and Optimal Monetary Policy.” Brookings Papers on Economic Activity (2):139-211.

Engelberg, Joseph, Charles F. Manski, and Jared Williams, 2009. "Comparing the Point Predictions and Subjective Probability Distributions of Professional Forecasters.” Journal of Business and Economic Statistics 27 (1): 30-41.

Hurd, Michael D., and Susann Rohwedder. 2013. "Measuring Total Household Spending in a Monthly Internet Survey: Evidence from the American Life Panel.” Working Paper No. 17974. Cambridge, MA: National Bureau of Economic Research.

Ichiue, Hibiki, and Shusaku Nishiguchi. 2013. "Inflation Expectations and Consumer Spending at the Zero Bound: Micro Evidence,” Bank of Japan Working Paper No. 13-E-11, July. Available at https://www.boj.or.jp/en/research/wps_rev/wps_2013/data/wp13e11.pdf. 
Ito, Aki, and Michelle Jamrisko. 2013. "Rogoff Saying This Time Different Calls for Reflation.” Bloomberg.com, August 12. Available at http://www.bloomberg.com/news/2013-08-12/rogoffsaying-this-time-different-calls-for-reflation-economy.html.

Krugman, Paul R. 1998. “It’s Baaack! Japan’s Slump and the Return of the Liquidity Trap.” Brookings Papers on Economic Activity (2): 157-187.

Krugman, Paul. 2013. “Not Enough Inflation.” New York Times, May 2.

Malmendier, Ulrike, and Stefan Nagel. 2013. “Learning from Inflation Experiences.” Manuscript. http://emlab.berkeley.edu/ ulrike/Papers/InflExp_44.pdf .

Manning, Willard G., 1998. “The Logged Dependent Variable, Heteroscedasticity, and the Retransformation Problem.” Journal of Health Economics 17(3): 283-295.

Manning, Willard G., and John Mullahy. 2001. "Estimating Log Models: To Transform or Not to Transform?” Journal of Health Economics 20(4): 461-494

Mishkin, Frederic S. 2010. "Whither Federal Reserve Communications.” Speech at the Peterson Institute for International Economics, Washington, DC, July 28. Available at http://www.federalreserve.gov/newsevents/speech/mishkin20080728a.htm.

Nichols, Austin. 2010. "Regression for Nonnegative Skewed Dependent Variables.” Slide presentation. File available on request.

Norris, Floyd. 2011. “Sometimes, Inflation is Not Evil.” New York Times, August 11.

RAND American Life Panel. https://mmicdata.rand.org/alp/.

Romer, Christina D. 2011. “Dear Ben: It’s Time for Your Volcker Moment.” New York Times, October 29.

Shiller, Robert J .1997.. “Why Do People Dislike Inflation?” In Reducing Inflation: Motivation and Strategy, ed. Christina D. Romer and David H. Romer, 13-65.Chicago: University of Chicago Press.

Woodford, Michael. 2012. "Methods of Policy Accommodation at the Interest-Rate Lower Bound.” Presented at “The Changing Policy Landscape,” 2012 FRB Kansas City Economic Policy Symposium, Jackson Hole, WY. Available at http://kansascityfed.org/publicat/sympos/2012/mw.pdf.

Wooldridge, Jeffrey M. 2002. Econometric Analysis of Cross Section and Panel Data. Cambridge, MA: The MIT Press. 
Table 1 Means of Key Variables

\begin{tabular}{lcc}
\hline & Durable Quarterly & Nondurable Monthly \\
\hline Durables & 383.96 & \\
Nondurables & $18,627.82$ & 951.15 \\
Income & $13,460.15$ & $6,765.46$ \\
Median Household Income & 3.35 & 3.047 .94 \\
Inflation Expectations & 2.12 & 2.08 \\
Inflation Uncertainty & 3.86 & 3.87 \\
Medium-Run Inflation Expectations & 2.52 & 2.49 \\
Medium-Run Inflation Uncertainty & -1.05 & -1.04 \\
Real Wage Expectations & 1.61 & 1.52 \\
Nominal Wage Uncertainty & 0.44 & 0.44 \\
Expect Interest Rates Rise & 0.05 & 0.04 \\
Expect Interest Rates Decline & 0.31 & 0.30 \\
Expect Unemployment Rise & 0.23 & 0.23 \\
Expect Unemployment Decline & 55.41 & 55.57 \\
Age & 0.94 & 0.94 \\
White & 0.49 & 0.47 \\
Female & 0.87 & 0.87 \\
Some College & 0.03 & 0.04 \\
Retired & 1,611 & 2,105 \\
\hline Number & & 50
\end{tabular}

Notes: All statistics refer to unweighted sample means except for median income, which refers to the median across households of within-household mean income. The latter is the mean of all available income observations for a given household. Households with less than four observations are dropped. Spending on durable goods is deflated using the $2012 \mathrm{CPI}$-U for durables. Income and spending on nondurable goods are deflated using the 2012 CPI-U for all items. 
Table 2 Short-Run Inflation Expectations and Quarterly Spending on Durable Goods

\begin{tabular}{|c|c|c|c|c|c|c|}
\hline & Poisson & Poisson(fe) & LnOLS & $\operatorname{LnOLS}(\mathrm{fe})$ & OLS & OLS $(f d)$ \\
\hline Infation Expectations & $\begin{array}{r}-.0158 \\
(.0369)\end{array}$ & $\begin{array}{r}-.0807^{*} \\
(.0434)\end{array}$ & $\begin{array}{r}-.0216 \\
(.0316)\end{array}$ & $\begin{array}{r}-.0927 \\
(.0619)\end{array}$ & $\begin{array}{c}-10.7 \\
(11.92)\end{array}$ & $\begin{array}{c}-19.99 \\
(22.61)\end{array}$ \\
\hline Inflation Uncertainty & $\begin{array}{l}.027 \\
(.0543)\end{array}$ & $\begin{array}{l}.0661 \\
(.0653)\end{array}$ & $\begin{array}{c}-.0137 \\
(.0423)\end{array}$ & $\begin{array}{l}.0539 \\
(.0816)\end{array}$ & $\begin{array}{r}7.901 \\
(19.04)\end{array}$ & $\begin{array}{r}30.52 \\
(28.9)\end{array}$ \\
\hline Log of Income & $\begin{array}{l}.5988^{* * *} \\
(.1222)\end{array}$ & $\begin{array}{l}.3448^{*} \\
(.1909)\end{array}$ & $\begin{array}{l}.315^{* * *} \\
(.0994)\end{array}$ & $\begin{array}{l}.099 \\
(.2186)\end{array}$ & & \\
\hline Income & & & & & $\begin{array}{c}.0029 \\
(.0025)\end{array}$ & $\begin{array}{r}-3.9 e-04 \\
(8.5 e-04)\end{array}$ \\
\hline Expect Interest Rates Rise & $\begin{array}{l}.1182 \\
(.2214)\end{array}$ & $\begin{array}{c}.1263 \\
(.1816)\end{array}$ & $\begin{array}{l}.2087 \\
(.1336)\end{array}$ & $\begin{array}{l}.1797 \\
(.2213)\end{array}$ & $\begin{array}{l}107.3 \\
(91.08)\end{array}$ & $\begin{array}{l}-65.92 \\
(106.3)\end{array}$ \\
\hline Expect Interest Rates Decline & $\begin{array}{c}-.3894 \\
(.3525)\end{array}$ & $\begin{array}{c}-.4402 \\
(.3528)\end{array}$ & $\begin{array}{l}.0202 \\
(.2356)\end{array}$ & $\begin{array}{c}-.0814 \\
(.557)\end{array}$ & $\begin{array}{r}-141.6^{*} \\
(83.59)\end{array}$ & $\begin{array}{l}-248^{*} \\
(130.1)\end{array}$ \\
\hline Expect Unemployment Rise & $\begin{array}{c}.0744 \\
(.304)\end{array}$ & $\begin{array}{l}.3236 \\
(.334)\end{array}$ & $\begin{array}{l}.1297 \\
(.1413)\end{array}$ & $\begin{array}{r}-.0503 \\
(.2432)\end{array}$ & $\begin{array}{c}-32.07 \\
(103.2)\end{array}$ & $\begin{array}{r}-72.15 \\
(70.83)\end{array}$ \\
\hline Expect Unemployment Decline & $\begin{array}{l}.183 \\
(.2012)\end{array}$ & $\begin{array}{l}.3779^{* *} \\
(.1759)\end{array}$ & $\begin{array}{l}.235^{*} \\
(.1343)\end{array}$ & $\begin{array}{l}.3501 \\
(.2226)\end{array}$ & $\begin{array}{c}89.06 \\
(97.59)\end{array}$ & $\begin{array}{c}126.5 \\
(119.9)\end{array}$ \\
\hline Real Wage Expectations & $\begin{array}{c}-.0124 \\
(.0179)\end{array}$ & $\begin{array}{r}-.0411^{*} \\
(.0228)\end{array}$ & $\begin{array}{c}-1.1 e-04 \\
(.017)\end{array}$ & $\begin{array}{c}-.0244 \\
(.0223)\end{array}$ & $\begin{array}{c}-5.49 \\
(4.235)\end{array}$ & $\begin{array}{c}-6.364 \\
(6.493)\end{array}$ \\
\hline Nominal Wage Uncertainty & $\begin{array}{r}-.0689^{*} \\
(.0379)\end{array}$ & $\begin{array}{l}-.033 \\
(.0395)\end{array}$ & $\begin{array}{l}-.038 \\
(.0281)\end{array}$ & $\begin{array}{l}.0046 \\
(.0525)\end{array}$ & $\begin{array}{c}-17.8^{*} \\
(10.69)\end{array}$ & $\begin{array}{l}-.7921 \\
(18.84)\end{array}$ \\
\hline Age & $\begin{array}{l}.0108 \\
(.0161)\end{array}$ & & $\begin{array}{l}.0291^{* *} \\
(.0136)\end{array}$ & & $\begin{array}{r}.1585 \\
(6.214)\end{array}$ & \\
\hline White & $\begin{array}{l}.0767 \\
(.3191)\end{array}$ & & $\begin{array}{c}-.2955 \\
(.3564)\end{array}$ & & $\begin{array}{r}81.84 \\
(111.8)\end{array}$ & \\
\hline Female & $\begin{array}{l}.2747 \\
(.2168)\end{array}$ & & $\begin{array}{c}-.0804 \\
(.143)\end{array}$ & & $\begin{array}{c}77.17 \\
(90.46)\end{array}$ & \\
\hline Some College & $\begin{array}{l}.1308 \\
(.2153)\end{array}$ & & $\begin{array}{c}-.3117 \\
(.2227)\end{array}$ & & $\begin{array}{r}87.06 \\
(87.9)\end{array}$ & \\
\hline Retired & $\begin{array}{r}-.6489 \\
(.5538)\end{array}$ & & $\begin{array}{c}-.5819 \\
(.3724)\end{array}$ & & $\begin{array}{r}-252.9^{* * *} \\
(88.36)\end{array}$ & \\
\hline Constant & $\begin{array}{c}-1.076 \\
(1.74)\end{array}$ & & $\begin{array}{c}1.581 \\
(1.388)\end{array}$ & $\begin{array}{c}5.139^{* *} \\
(2.171)\end{array}$ & $\begin{array}{c}228.1 \\
(406.4)\end{array}$ & \\
\hline Fixed Effects & No & Yes & No & Yes & No & No \\
\hline $\mathrm{R}^{2}$ & & & 0.089 & 0.470 & 0.021 & 0.006 \\
\hline $\mathrm{Chi}^{2}$ & 72.21 & 53.05 & & & & \\
\hline Number & 1,427 & 1,260 & 522 & 522 & 1,610 & 1,397 \\
\hline
\end{tabular}


Table 3 Medium-Run Inflation Expectations and Quarterly Spending on Durable Goods

\begin{tabular}{|c|c|c|c|c|c|c|}
\hline & Poisson & Poisson(fe) & LnOLS & $\operatorname{LnOLS}(\mathrm{fe})$ & OLS & OLS(fd) \\
\hline Medium-Run Inflation Expectations & $\begin{array}{c}-.0093 \\
(.0308)\end{array}$ & $\begin{array}{c}-.0431 \\
(.0348)\end{array}$ & $\begin{array}{c}-.0051 \\
(.0225)\end{array}$ & $\begin{array}{l}-.0565 \\
(.04)\end{array}$ & $\begin{array}{l}-.8011 \\
(9.522)\end{array}$ & $\begin{array}{l}-8.9 \\
(11.3)\end{array}$ \\
\hline Medium-Run Inflation Uncertainty & $\begin{array}{c}-.0588 \\
(.0463)\end{array}$ & $\begin{array}{c}-.0472 \\
(.0546)\end{array}$ & $\begin{array}{c}-.0495 \\
(.0333)\end{array}$ & $\begin{array}{l}.0439 \\
(.0523)\end{array}$ & $\begin{array}{c}-19.5 \\
(13.5)\end{array}$ & $\begin{array}{c}-43.35 \\
(32.32)\end{array}$ \\
\hline Log of Income & $\begin{array}{l}.6063^{* * *} \\
(.1236)\end{array}$ & $\begin{array}{r}.3399^{*} \\
(.1909)\end{array}$ & $\begin{array}{l}.3127^{* * *} \\
(.0978)\end{array}$ & $\begin{array}{l}.1016 \\
(.2203)\end{array}$ & & \\
\hline Income & & & & & $\begin{array}{l}.003 \\
(.0025)\end{array}$ & $\begin{array}{r}-2.8 e-04 \\
(8.1 e-04)\end{array}$ \\
\hline Expect Interest Rates Rise & $\begin{array}{l}.1481 \\
(.2244)\end{array}$ & $\begin{array}{l}.1467 \\
(.1841)\end{array}$ & $\begin{array}{l}.2203^{*} \\
(.1327)\end{array}$ & $\begin{array}{l}.163 \\
(.2201)\end{array}$ & $\begin{array}{l}110.5 \\
(92.18)\end{array}$ & $\begin{array}{c}-63.58 \\
(98.78)\end{array}$ \\
\hline Expect Interest Rates Decline & $\begin{array}{c}-.3957 \\
(.3618)\end{array}$ & $\begin{array}{c}-.4655 \\
(.3694)\end{array}$ & $\begin{array}{l}.0245 \\
(.2332)\end{array}$ & $\begin{array}{l}-.137 \\
(.5772)\end{array}$ & $\begin{array}{r}-137.2 \\
(84.8)\end{array}$ & $\begin{array}{c}-263.1^{* *} \\
(132.1)\end{array}$ \\
\hline Expect Unemployment Rise & $\begin{array}{l}.074 \\
(.3001)\end{array}$ & $\begin{array}{l}.2934 \\
(.3276)\end{array}$ & $\begin{array}{l}.1266 \\
(.1378)\end{array}$ & $\begin{array}{r}-.0401 \\
(.247)\end{array}$ & $\begin{array}{l}-36.04 \\
(102.6)\end{array}$ & $\begin{array}{c}-74.97 \\
(71.85)\end{array}$ \\
\hline Expect Unemployment Decline & $\begin{array}{l}.1777 \\
(.1991)\end{array}$ & $\begin{array}{l}.348^{*} \\
(.1833)\end{array}$ & $\begin{array}{l}.2419^{*} \\
(.1344)\end{array}$ & $\begin{array}{l}.3472 \\
(.2217)\end{array}$ & $\begin{array}{r}85.97 \\
(96.3)\end{array}$ & $\begin{array}{l}118 \\
(118.2)\end{array}$ \\
\hline Real Wage Expectations & $\begin{array}{l}-.015 \\
(.0184)\end{array}$ & $\begin{array}{c}-.0349 \\
(.0244)\end{array}$ & $\begin{array}{l}.0014 \\
(.0163)\end{array}$ & $\begin{array}{c}-.0071 \\
(.0251)\end{array}$ & $\begin{array}{l}-4.54 \\
(4.739)\end{array}$ & $\begin{array}{c}-8.345 \\
(9.242)\end{array}$ \\
\hline Nominal Wage Uncertainty & $\begin{array}{r}-.0395 \\
(.0338)\end{array}$ & $\begin{array}{c}-.0204 \\
(.041)\end{array}$ & $\begin{array}{c}-.0259 \\
(.0267)\end{array}$ & $\begin{array}{l}.0016 \\
(.0503)\end{array}$ & $\begin{array}{r}-8.395 \\
(8.776)\end{array}$ & $\begin{array}{r}7.907 \\
(19.17)\end{array}$ \\
\hline Age & $\begin{array}{l}.0108 \\
(.0164)\end{array}$ & & $\begin{array}{l}.0275^{* *} \\
(.0135)\end{array}$ & & $\begin{array}{l}-.4707 \\
(6.234)\end{array}$ & \\
\hline White & $\begin{array}{l}.0469 \\
(.2995)\end{array}$ & & $\begin{array}{l}-.298 \\
(.3383)\end{array}$ & & $\begin{array}{c}67.6 \\
(106.5)\end{array}$ & \\
\hline Female & $\begin{array}{l}.2595 \\
(.2147)\end{array}$ & & $\begin{array}{l}-.084 \\
(.1417)\end{array}$ & & $\begin{array}{r}77.08 \\
(90.6)\end{array}$ & \\
\hline Some College & $\begin{array}{l}.1321 \\
(.2239)\end{array}$ & & $\begin{array}{c}-.3235 \\
(.2272)\end{array}$ & & $\begin{array}{c}91.77 \\
(89.62)\end{array}$ & \\
\hline Retired & $\begin{array}{r}-.6103 \\
(.5417)\end{array}$ & & $\begin{array}{c}-.5653 \\
(.362)\end{array}$ & & $\begin{array}{r}-243.5^{* * *} \\
(83.39)\end{array}$ & \\
\hline Constant & $\begin{array}{l}-1.02 \\
(1.713)\end{array}$ & & $\begin{array}{c}1.688 \\
(1.358)\end{array}$ & $\begin{array}{l}5.029^{* *} \\
(2.134)\end{array}$ & $\begin{array}{l}296.8 \\
(400)\end{array}$ & \\
\hline Fixed Effects & No & Yes & No & Yes & No & No \\
\hline $\mathrm{R}^{2}$ & & & 0.092 & 0.467 & 0.021 & 0.008 \\
\hline $\mathrm{Chi}^{2}$ & 73.67 & 43.55 & & & & \\
\hline Number & 1,427 & 1,260 & 522 & 522 & 1,610 & 1,397 \\
\hline
\end{tabular}


Table 4 Short-Run (SR) and Medium-Run (MR) Inflation Expectations and the Quarterly Number of Durable Goods Purchased

\begin{tabular}{|c|c|c|c|c|}
\hline & Poisson & Poisson(fe) & Poisson & Poisson(fe) \\
\hline & $\mathrm{SR}$ & $\mathrm{SR}$ & MR & MR \\
\hline \multirow[t]{2}{*}{ Inflation Expectations } & -.0053 & -.0167 & $8.0 e-04$ & -.0071 \\
\hline & $(.0177)$ & $(.0239)$ & $(.0151)$ & $(.0171)$ \\
\hline \multirow[t]{2}{*}{ Inflation Uncertainty } & .0231 & -.0271 & .0185 & -.0235 \\
\hline & $(.0222)$ & $(.0321)$ & $(.019)$ & $(.024)$ \\
\hline \multirow[t]{2}{*}{ Log of Income } & $.2434^{* * *}$ & $.1856^{*}$ & $.2464^{* * *}$ & $.1859^{*}$ \\
\hline & $(.0535)$ & $(.1062)$ & $(.0538)$ & $(.1078)$ \\
\hline \multirow[t]{2}{*}{ Expect Interest Rates Rise } & $.1513^{*}$ & .0666 & $.1468^{*}$ & .0683 \\
\hline & $(.0841)$ & $(.0865)$ & $(.0849)$ & $(.0878)$ \\
\hline \multirow[t]{2}{*}{ Expect Interest Rates Decline } & -.0255 & -.1011 & -.0184 & -.1001 \\
\hline & $(.1834)$ & $(.2392)$ & $(.1832)$ & $(.2401)$ \\
\hline \multirow[t]{2}{*}{ Expect Unemployment Rise } & $-.1756^{*}$ & -.0825 & $-.1738^{*}$ & -.0836 \\
\hline & $(.0967)$ & $(.1079)$ & $(.0965)$ & $(.1077)$ \\
\hline \multirow[t]{2}{*}{ Expect Unemployment Decline } & -.0275 & .0517 & -.0256 & .0506 \\
\hline & $(.1)$ & $(.1019)$ & $(.0998)$ & $(.1026)$ \\
\hline \multirow[t]{2}{*}{ Real Wage Expectations } & .0029 & -.0149 & .0037 & -.0085 \\
\hline & $(.0086)$ & $(.0128)$ & $(.0081)$ & $(.0112)$ \\
\hline \multirow[t]{2}{*}{ Nominal Wage Uncertainty } & .002 & .013 & .0023 & .0095 \\
\hline & $(.0181)$ & $(.023)$ & $(.0175)$ & $(.0229)$ \\
\hline \multirow[t]{2}{*}{ Age } & -.0081 & & -.0082 & \\
\hline & $(.0076)$ & & $(.0077)$ & \\
\hline \multirow[t]{2}{*}{ White } & .0291 & & .0257 & \\
\hline & $(.1697)$ & & $(.1687)$ & \\
\hline \multirow[t]{2}{*}{ Female } & .0517 & & .0493 & \\
\hline & $(.0789)$ & & $(.0789)$ & \\
\hline \multirow[t]{2}{*}{ Some College } & .1472 & & .1466 & \\
\hline & $(.1286)$ & & $(.1289)$ & \\
\hline \multirow[t]{2}{*}{ Retired } & -.0796 & & -.0875 & \\
\hline & $(.2768)$ & & $(.2753)$ & \\
\hline \multirow[t]{2}{*}{ Constant } & $-2.273^{* * *}$ & & $-2.309^{* * *}$ & \\
\hline & $(.6797)$ & & $(.6786)$ & \\
\hline Fixed Effects & No & Yes & No & Yes \\
\hline $\mathrm{Chi}^{2}$ & 78.736 & 68.914 & 80.158 & 64.440 \\
\hline Number & 1,427 & 1,299 & 1,427 & 1,299 \\
\hline
\end{tabular}

Notes: Standard errors are clustered at the individual level and reported in parentheses. Quarterly time dummy variables are included in all models. The symbol * indicates significance at the 10 -percent level; ${ }^{* *}$ indicates significance at the 5 -percent level; ${ }^{* * *}$ indicates significance at the 1-percent level. The abbreviation (fe) refers to fixed effects. 
Table 5 Short-Run Inflation Expectations and Monthly Spending on Nondurable Goods

\begin{tabular}{|c|c|c|c|c|c|c|}
\hline & Poisson & Poisson(fe) & LnOLS & $\operatorname{LnOLS}(\mathrm{fe})$ & OLS & OLS(fd) \\
\hline Inflation Expectations & $\begin{array}{l}8.9 e-04 \\
(.0098)\end{array}$ & $\begin{array}{c}.011^{* *} \\
(.0054)\end{array}$ & $\begin{array}{l}.0024 \\
(.0094)\end{array}$ & $\begin{array}{l}.009^{*} \\
(.0052)\end{array}$ & $\begin{array}{c}-13.41 \\
(21.01)\end{array}$ & $\begin{array}{l}26.28^{*} \\
(13.6)\end{array}$ \\
\hline Inflation Uncertainty & $\begin{array}{l}.0404^{* * *} \\
(.0137)\end{array}$ & $\begin{array}{c}-.0044 \\
(.0063)\end{array}$ & $\begin{array}{l}.0409^{* * *} \\
(.0136)\end{array}$ & $\begin{array}{c}-.0032 \\
(.0058)\end{array}$ & $\begin{array}{c}69.16^{* *} \\
(33.12)\end{array}$ & $\begin{array}{r}8.786 \\
(14.62)\end{array}$ \\
\hline Log of Income & $\begin{array}{l}.3224^{* * *} \\
(.037)\end{array}$ & $\begin{array}{l}.0579^{* *} \\
(.0274)\end{array}$ & $\begin{array}{l}.3296^{* * *} \\
(.0355)\end{array}$ & $\begin{array}{l}.0631^{* * *} \\
(.0229)\end{array}$ & & \\
\hline Income & & & & & $\begin{array}{c}.0141^{*} \\
(.0082)\end{array}$ & $\begin{array}{c}-8.3 e-04 \\
\quad(.0013)\end{array}$ \\
\hline Expect Interest Rates Rise & $\begin{array}{c}.0273 \\
(.0365)\end{array}$ & $\begin{array}{l}.0541^{* * *} \\
(.0209)\end{array}$ & $\begin{array}{c}.0054 \\
(.0379)\end{array}$ & $\begin{array}{c}.0264 \\
(.0196)\end{array}$ & $\begin{array}{c}84.75 \\
(75.25)\end{array}$ & $\begin{array}{c}86.84^{*} \\
(47.48)\end{array}$ \\
\hline Expect Interest Rates Decline & $\begin{array}{c}-.1176 \\
(.076)\end{array}$ & $\begin{array}{c}.0561 \\
(.0542)\end{array}$ & $\begin{array}{c}-.0474 \\
(.0689)\end{array}$ & $\begin{array}{l}.0647 \\
(.0479)\end{array}$ & $\begin{array}{c}-167.2 \\
(137.3)\end{array}$ & $\begin{array}{c}80.18 \\
(77.78)\end{array}$ \\
\hline Expect Unemployment Rise & $\begin{array}{r}-.0963^{*} \\
(.0571)\end{array}$ & $\begin{array}{c}-.0099 \\
(.0217)\end{array}$ & $\begin{array}{c}-.0571 \\
(.0485)\end{array}$ & $\begin{array}{c}-.0082 \\
(.0225)\end{array}$ & $\begin{array}{c}-279.2^{* *} \\
(115.3)\end{array}$ & $\begin{array}{c}40.32 \\
(43.56)\end{array}$ \\
\hline Expect Unemployment Decline & $\begin{array}{c}-.0685 \\
(.0473)\end{array}$ & $\begin{array}{c}.0095 \\
(.0249)\end{array}$ & $\begin{array}{c}-.0278 \\
(.052)\end{array}$ & $\begin{array}{l}.0268 \\
(.0238)\end{array}$ & $\begin{array}{l}-60.1 \\
(106.3)\end{array}$ & $\begin{array}{l}101.2^{*} \\
(52.14)\end{array}$ \\
\hline Real Wage Expectations & $\begin{array}{c}.0098^{*} \\
(.0052)\end{array}$ & $\begin{array}{l}.0044 \\
(.0035)\end{array}$ & $\begin{array}{l}.0087 \\
(.0054)\end{array}$ & $\begin{array}{l}.0048 \\
(.0034)\end{array}$ & $\begin{array}{r}8.161 \\
(12.87)\end{array}$ & $\begin{array}{c}21.92^{*} \\
(11.41)\end{array}$ \\
\hline Nominal Wage Uncertainty & $\begin{array}{c}.0074 \\
(.0096)\end{array}$ & $\begin{array}{l}.0018 \\
(.0049)\end{array}$ & $\begin{array}{l}.0087 \\
(.0091)\end{array}$ & $\begin{array}{l}.0015 \\
(.0049)\end{array}$ & $\begin{array}{c}36.17 \\
(25.44)\end{array}$ & $\begin{array}{c}16.31 \\
(13.59)\end{array}$ \\
\hline Age & $\begin{array}{c}-.0022 \\
(.006)\end{array}$ & & $\begin{array}{c}-7.3 e-04 \\
(.0055)\end{array}$ & & $\begin{array}{c}-15.36 \\
(12.74)\end{array}$ & \\
\hline White & $\begin{array}{l}.1301 \\
(.118)\end{array}$ & & $\begin{array}{c}.2007 \\
(.1253)\end{array}$ & & $\begin{array}{c}378.8 \\
(231.9)\end{array}$ & \\
\hline Female & $\begin{array}{l}.0672 \\
(.0605)\end{array}$ & & $\begin{array}{l}.1139^{*} \\
(.0593)\end{array}$ & & $\begin{array}{c}117.7 \\
(132.6)\end{array}$ & \\
\hline Some College & $\begin{array}{l}.1183 \\
(.0987)\end{array}$ & & $\begin{array}{l}.0745 \\
(.0974)\end{array}$ & & $\begin{array}{c}463.1^{* *} \\
(186.7)\end{array}$ & \\
\hline Retired & $\begin{array}{l}.0035 \\
(.1331)\end{array}$ & & $\begin{array}{l}.0261 \\
(.1445)\end{array}$ & & $\begin{array}{c}-507.5^{* *} \\
(256.9)\end{array}$ & \\
\hline Constant & $\begin{array}{l}4.621^{* * *} \\
(.4486)\end{array}$ & & $\begin{array}{l}4.386^{* * *} \\
(.5019)\end{array}$ & $\begin{array}{c}6.869^{* * *} \\
(.2097)\end{array}$ & $\begin{array}{l}2,514^{* * *} \\
(722.6)\end{array}$ & \\
\hline Fixed Effects & No & Yes & No & Yes & No & No \\
\hline $\begin{array}{l}\mathrm{R}^{2} \\
\mathrm{Chi}^{2}\end{array}$ & 259.3 & 194.5 & 0.289 & 0.808 & 0.116 & 0.030 \\
\hline Number & 1,765 & 1,772 & 1,765 & 1,773 & 2,074 & 1,849 \\
\hline
\end{tabular}


Table 6 Medium-Run Inflation Expectations and Monthly Spending on Nondurable Goods

\begin{tabular}{|c|c|c|c|c|c|c|}
\hline & Poisson & Poisson(fe) & LnOLS & $\operatorname{LnOLS}(\mathrm{fe})$ & OLS & OLS(fd) \\
\hline Medium-Run Inflation Expectations & $\begin{array}{c}.0041 \\
(.0085)\end{array}$ & $\begin{array}{c}.0014 \\
(.0045)\end{array}$ & $\begin{array}{c}.0062 \\
(.0079)\end{array}$ & $\begin{array}{c}.0022 \\
(.0041)\end{array}$ & $\begin{array}{r}1.237 \\
(18.05)\end{array}$ & $\begin{array}{c}5.69 \\
(9.432)\end{array}$ \\
\hline Medium-Run Inflation Uncertainty & $\begin{array}{l}.0265^{* *} \\
(.0123)\end{array}$ & $\begin{array}{c}-.0046 \\
(.006)\end{array}$ & $\begin{array}{l}.0261^{* *} \\
(.0118)\end{array}$ & $\begin{array}{l}-.004 \\
(.0051)\end{array}$ & $\begin{array}{c}45.53 \\
(28.21)\end{array}$ & $\begin{array}{r}2.341 \\
(12.08)\end{array}$ \\
\hline Log of Income & $\begin{array}{l}.3242^{* * *} \\
(.0372)\end{array}$ & $\begin{array}{l}.0585^{* *} \\
(.027)\end{array}$ & $\begin{array}{l}.3295^{* * *} \\
(.0359)\end{array}$ & $\begin{array}{l}.0633^{* * *} \\
(.0227)\end{array}$ & & \\
\hline Income & & & & & $\begin{array}{c}.0145^{*} \\
(.0082)\end{array}$ & $\begin{array}{c}-7.8 e-04 \\
(.0013)\end{array}$ \\
\hline Expect Interest Rates Rise & $\begin{array}{c}.0284 \\
(.0371)\end{array}$ & $\begin{array}{l}.0584^{* * *} \\
(.0212)\end{array}$ & $\begin{array}{c}.0049 \\
(.038)\end{array}$ & $\begin{array}{c}.0286 \\
(.0196)\end{array}$ & $\begin{array}{c}76.72 \\
(75.57)\end{array}$ & $\begin{array}{l}96.32^{* *} \\
(48.48)\end{array}$ \\
\hline Expect Interest Rates Decline & $\begin{array}{r}-.1082 \\
(.0762)\end{array}$ & $\begin{array}{c}.0574 \\
(.0551)\end{array}$ & $\begin{array}{c}-.0373 \\
(.069)\end{array}$ & $\begin{array}{c}.0655 \\
(.0485)\end{array}$ & $\begin{array}{c}-154.8 \\
(139.2)\end{array}$ & $\begin{array}{c}74.83 \\
(77.88)\end{array}$ \\
\hline Expect Unemployment Rise & $\begin{array}{r}-.0896 \\
(.0578)\end{array}$ & $\begin{array}{r}-.0077 \\
(.022)\end{array}$ & $\begin{array}{c}-.0519 \\
(.049)\end{array}$ & $\begin{array}{r}-.0069 \\
(.0227)\end{array}$ & $\begin{array}{l}-275.5^{* *} \\
(116)\end{array}$ & $\begin{array}{c}45.23 \\
(44.68)\end{array}$ \\
\hline Expect Unemployment Decline & $\begin{array}{r}-.0696 \\
(.0479)\end{array}$ & $\begin{array}{c}.0101 \\
(.0251)\end{array}$ & $\begin{array}{r}-.0275 \\
(.0524)\end{array}$ & $\begin{array}{c}.0266 \\
(.0241)\end{array}$ & $\begin{array}{l}-54.62 \\
(106.4)\end{array}$ & $\begin{array}{l}102.9^{*} \\
(52.33)\end{array}$ \\
\hline Real Wage Expectations & $\begin{array}{c}.0086^{*} \\
(.0048)\end{array}$ & $\begin{array}{c}.0019 \\
(.0032)\end{array}$ & $\begin{array}{c}.0075 \\
(.0048)\end{array}$ & $\begin{array}{r}.0027 \\
(.003)\end{array}$ & $\begin{array}{r}9.782 \\
(11.41)\end{array}$ & $\begin{array}{l}12.71 \\
(8.335)\end{array}$ \\
\hline Nominal Wage Uncertainty & $\begin{array}{c}.0106 \\
(.0096)\end{array}$ & $\begin{array}{c}.0029 \\
(.0048)\end{array}$ & $\begin{array}{r}.0117 \\
(.009)\end{array}$ & $\begin{array}{c}.0025 \\
(.0048)\end{array}$ & $\begin{array}{c}38.93 \\
(25.58)\end{array}$ & $\begin{array}{c}21.87 \\
(13.48)\end{array}$ \\
\hline Age & $\begin{array}{c}-.0024 \\
(.0061)\end{array}$ & & $\begin{array}{c}-9.6 e-04 \\
(.0056)\end{array}$ & & $\begin{array}{r}-15.95 \\
(12.76)\end{array}$ & \\
\hline White & $\begin{array}{c}.1261 \\
(.1196)\end{array}$ & & $\begin{array}{c}.1957 \\
(.1275)\end{array}$ & & $\begin{array}{c}367.7 \\
(236.6)\end{array}$ & \\
\hline Female & $\begin{array}{c}.0584 \\
(.0608)\end{array}$ & & $\begin{array}{c}.1042^{*} \\
(.0598)\end{array}$ & & $\begin{array}{c}102.6 \\
(133.7)\end{array}$ & \\
\hline Some College & $\begin{array}{c}.1195 \\
(.0976)\end{array}$ & & $\begin{array}{c}.0768 \\
(.0961)\end{array}$ & & $\begin{array}{c}466.4^{* *} \\
(186.8)\end{array}$ & \\
\hline Retired & $\begin{array}{c}-.005 \\
(.1383)\end{array}$ & & $\begin{array}{c}.0102 \\
(.1488)\end{array}$ & & $\begin{array}{c}-533.3^{* *} \\
(263.5)\end{array}$ & \\
\hline Constant & $\begin{array}{l}4.622^{* * *} \\
(.4539)\end{array}$ & & $\begin{array}{l}4.315^{* * *} \\
(.5401)\end{array}$ & $\begin{array}{l}6.887^{* * *} \\
(.2077)\end{array}$ & $\begin{array}{l}2,591^{* * *} \\
(722.3)\end{array}$ & \\
\hline Fixed Effects & No & Yes & No & Yes & No & No \\
\hline $\mathrm{R}^{2}$ & & & 0.282 & 0.808 & 0.112 & 0.025 \\
\hline $\mathrm{Chi}^{2}$ & 265.2 & 190 & & & & \\
\hline Number & 1,765 & 1,772 & 1,765 & 1,773 & 2,074 & 1,849 \\
\hline
\end{tabular}


Table 7 Interaction Results for Quarterly Spending on Durable Goods

\begin{tabular}{lcc}
\hline & Poisson & Poisson(fe) \\
\hline Inflation Expectations & -.0225 & -.0870 \\
No Retirement Account & -.4994 & -.5523 \\
Inflation Expectations ${ }^{*}$ No Retirement Account & .0927 & .0648 \\
\hline Inflation Expectations & .0058 & -.0751 \\
No Stocks & -.0148 & .5557 \\
Inflation Expectations ${ }^{*}$ No Stocks & -.0434 & -.0199 \\
\hline Inflation Expectations & -.0203 & .0302 \\
Homeowner(Mortgage) & $1.0391^{* * *}$ & -.1501 \\
Inflation Expectations ${ }^{*}$ Homeowner(Mortgage) & -.0162 & -.1438 \\
Homeowner(No Mortgage) & $1.0943^{* * *}$ & -.4363 \\
Inflation Expectations ${ }^{*}$ Homeowner(No Mortgage) & .0957 & -.0625 \\
\hline
\end{tabular}

Notes: Coefficient estimates were produced using models similar to those in Table 2, columns 1 and 2, with the addition of the interaction terms shown above. The symbol * indicates significance at the 10-percent level; ${ }^{* *}$ indicates significance at the 5 -percent level; ${ }^{* * *}$ indicates significance at the 1 -percent level. 
Table 8 Interaction Results for Monthly Spending on Nondurable Goods

\begin{tabular}{|c|c|c|}
\hline & Poisson & Poisson(fe) \\
\hline Inflation Expectations & -.0063 & $.0106^{*}$ \\
\hline No Retirement Account & $-.4840^{* * *}$ & -.0237 \\
\hline Inflation Expectations $*$ No Retirement Account & $.0826^{* * *}$ & .0034 \\
\hline Inflation Expectations & -.0083 & .0104 \\
\hline No Stocks & $-.1857^{* *}$ & .0595 \\
\hline Inflation Expectations $*$ No Stocks & .0190 & .0018 \\
\hline Inflation Expectations & -.0009 & .0021 \\
\hline Homeowner(Mortgage) & .1700 & .0120 \\
\hline Inflation Expectations $*$ Homeowner(Mortgage) & -.0045 & .0098 \\
\hline Homeowner(No Mortgage) & .0437 & -.1069 \\
\hline Inflation Expectations * Homeowner(No Mortgage) & .0268 & $.0453^{* * *}$ \\
\hline
\end{tabular}

Notes: Coefficient estimates were produced using models similar to those in Table 5, columns 1 and 2, with the addition of the interaction terms shown above. The symbol * indicates significance at the 10-percent level; ${ }^{* *}$ indicates significance at the 5 -percent level; ${ }^{* * *}$ indicates significance at the 1 -percent level. 
Table 9 The Effects of Inflation Expectations for Spending on Specific Goods

\begin{tabular}{|c|c|c|}
\hline Durable Goods & Coefficient on Inflation Expectations & P-value \\
\hline Refrigerator & $-.5735^{* *}$ & .0204 \\
\hline Oven & -.0369 & .8696 \\
\hline Washer/Dryer & -.1003 & .5852 \\
\hline Dishwasher & -.5675 & .2074 \\
\hline Television & -.0006 & .9957 \\
\hline Computer & .0188 & .7490 \\
\hline Furniture & $-.1454^{*}$ & .0942 \\
\hline \multicolumn{3}{|l|}{ Nondurable Goods } \\
\hline Clothing & $.0315^{* *}$ & 0399 \\
\hline Food Home & -.0111 & .6524 \\
\hline Food Away & -.0188 & .1229 \\
\hline Phone/Cable/Internet & -.0019 & .6082 \\
\hline Gasoline & .0092 & .2598 \\
\hline Sporting Goods/Services & .0880 & .1398 \\
\hline Hobbies/Leisure & .0279 & .4997 \\
\hline Electricity & .0076 & .1932 \\
\hline Water & $.0192^{* *}$ & .0418 \\
\hline Heating Fuel & -.0255 & .3133 \\
\hline Cleaning Products & .0056 & .8331 \\
\hline Cleaning Services & $.0430^{* *}$ & .0264 \\
\hline Garden Products & -.0405 & .3011 \\
\hline Garden Services & -.1449 & .1852 \\
\hline Personal Care Goods & .0030 & .8821 \\
\hline Personal Care Services & -.0381 & .6384 \\
\hline Entertainment & .0067 & .8893 \\
\hline Education & .0035 & .9537 \\
\hline Other Child Spending & -.0041 & .9343 \\
\hline Medical Supplies & -.1033 & .2453 \\
\hline Health Care & .0301 & .4063 \\
\hline Prescription Drugs & .0018 & .9369 \\
\hline
\end{tabular}

Notes: Coefficient estimates were produced using Poisson models with household fixed effects (using Stata's xtpoisson command). In cases of durable goods, quarterly time dummies are included; in cases of nondurable goods, monthly time dummies are included. Spending values for specific goods categories are deflated, respectively, using the $2012 \mathrm{CPI}-\mathrm{U}$ for the goods category or special index that most closely matches the spending category. The symbol ${ }^{*}$ indicates significance at the 10 -percent level; ${ }^{* *}$ indicates significance at the 5-percent level; ${ }^{* * *}$ indicates significance at the 1-percent level. 
Table 10 The Effects of Short-Run Inflation Expectations on Purchase Decisions For Durable Goods

\begin{tabular}{lcc}
\hline & Coefficient on Inflation Expectations & P-value \\
\hline Buy Car & $.1708^{*}$ & .0599 \\
Buy Refrigerator & -.2608 & .2447 \\
Buy Oven & .1405 & .5501 \\
Buy Washer/Dryer & .0297 & .8589 \\
Buy Dishwasher & -.7863 & .2141 \\
Buy Television & .0379 & .6634 \\
Buy Computer & .0354 & .4685 \\
\hline
\end{tabular}

Notes: Coefficient estimates were produced using Poisson models with quarterly time dummies and household fixed effects (using Stata's xtpoisson command). The symbol * indicates significance at the 10-percent level; ${ }^{* *}$ indicates significance at the 5 -percent level; ${ }^{* * *}$ indicates significance at the 1 -percent level. 
Figure 1 Within-Household Inflation Expectations: First Difference Distributions
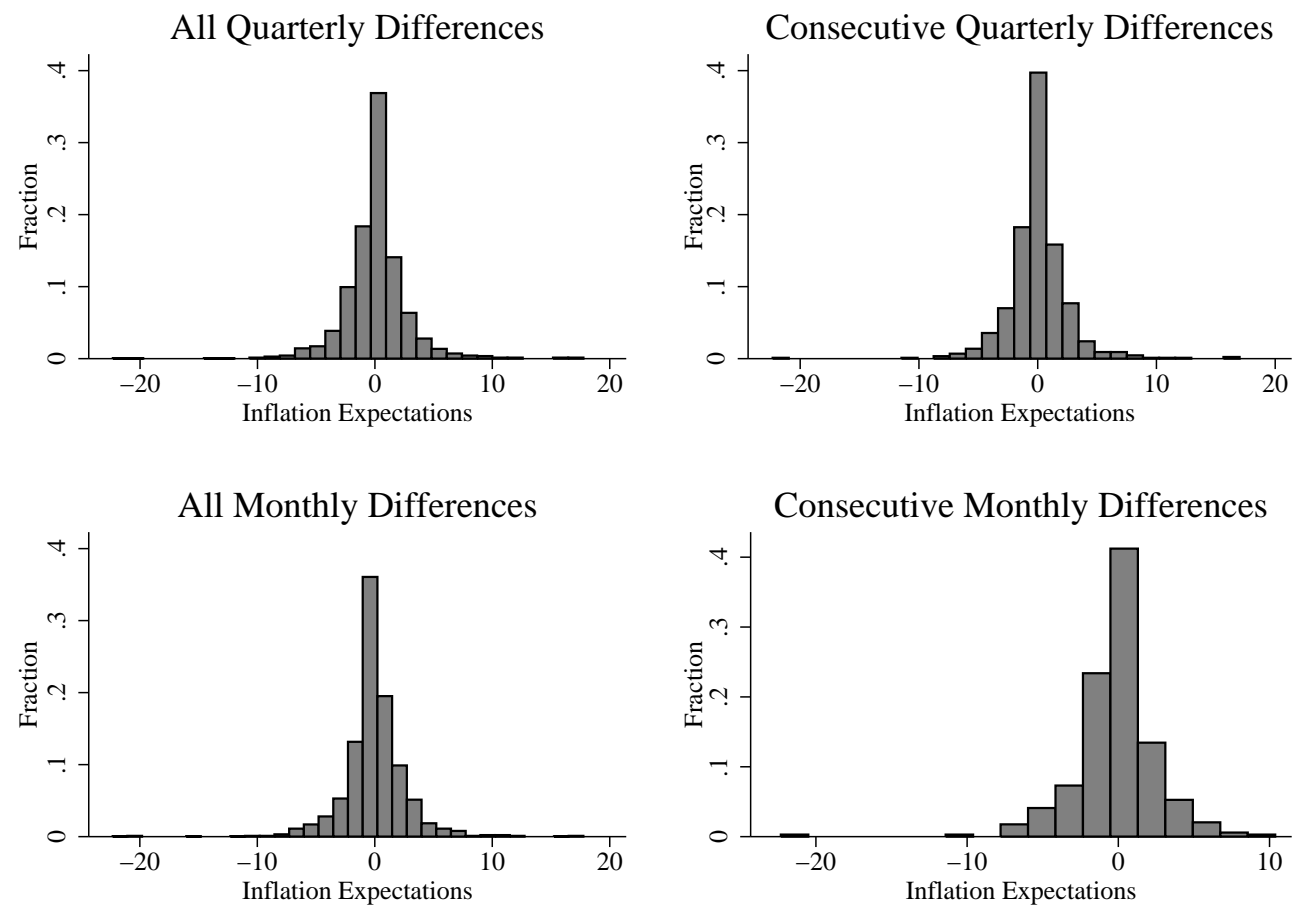

Notes: The histograms depict distributions of household-level first differences in inflation expectations taken from the survey data, for either the quarterly sample (top row) or the monthly sample (bottom row). Differences are calculated between any two successive observations of inflation expectations for the same household, with the more recent observation entering first. Owing to gaps in the data, some differences refer to non-consecutive months (or non-consecutive quarters). Within a row, the plot on the left includes all differences, and the plot on the right includes only consecutive differences. 
Figure 2 One-Year Ahead Inflation Expectations and Realized Inflation

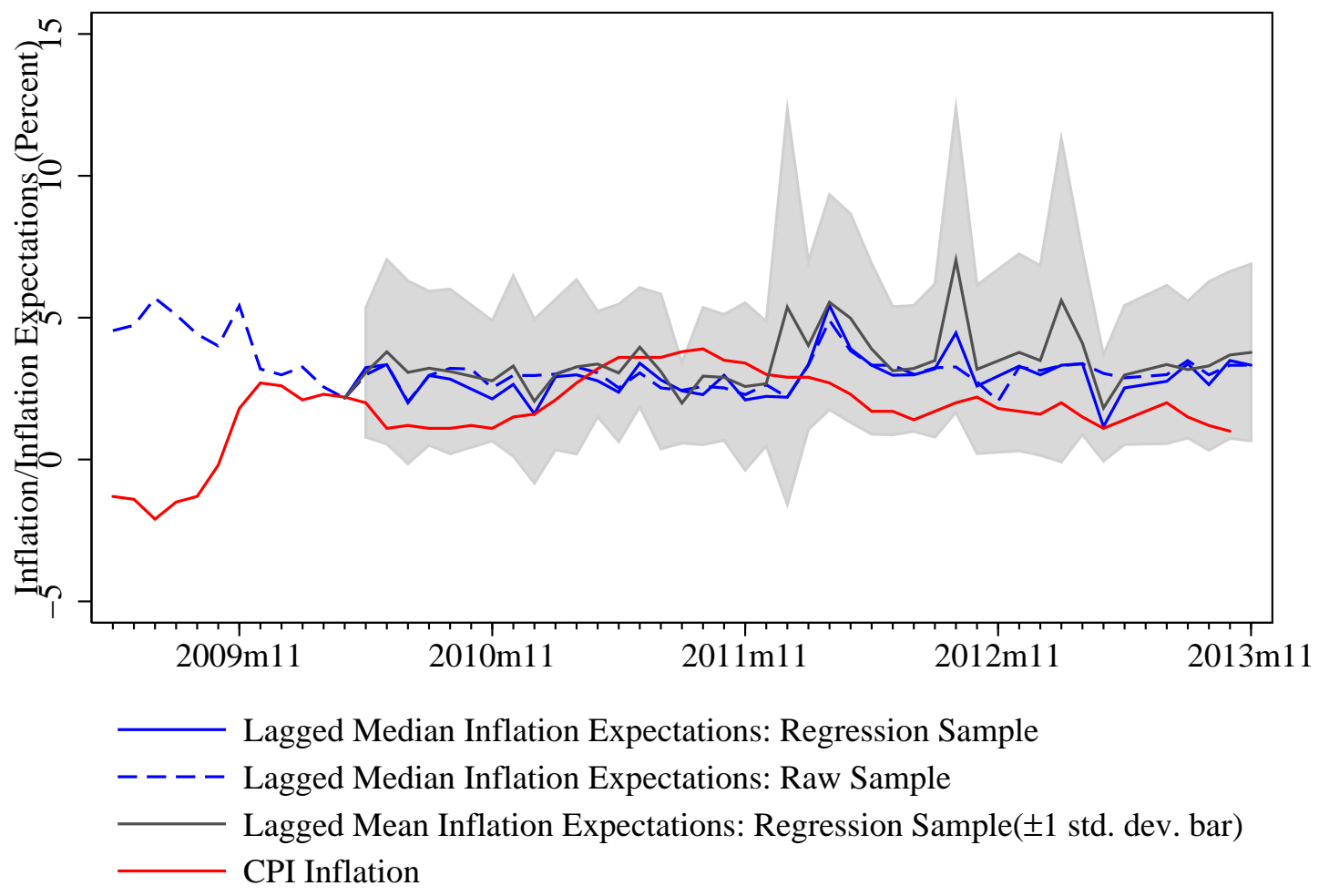

Notes: "CPI inflation" refers to the year-over-year percent change in the CPI-U All Items Index, sourced from Haver. Inflation expectations were formed one year prior to the indicated date and therefore represent median (or mean) inflation forecasts. "Regression sample" refers to the sample used in the regressions of nondurable goods spending on inflation expectations and other variables. "Raw sample" refers to the complete sample of inflation expectations, regardless of the availability of other variables. The shaded region represents one standard deviation above and below the lagged mean inflation expectations for the regression sample. 
Figure 3 Relative Price Changes for Specific Goods Categories
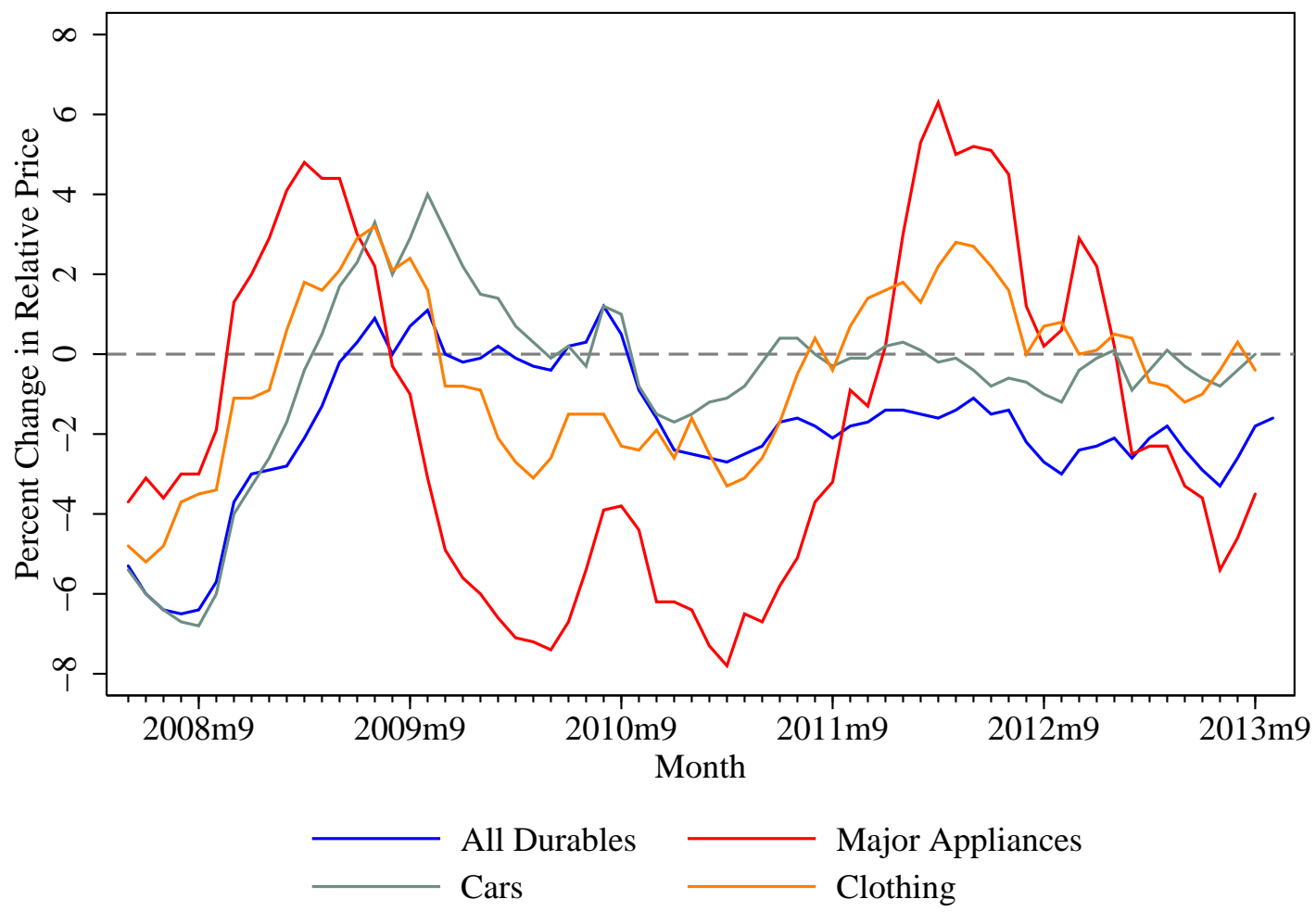

Notes: Values are based on authors' calculations using CPI inflation data from Haver. A given plot represents the difference between the year-over-year percent change in the CPI-U for the specific goods category and the year-over-year percent change in the CPI-U All Items Index. 